\title{
The antimicrobial protein, CAP37, is upregulated in pyramidal neurons during Alzheimer's disease
}

\author{
Amanda J. Brock ${ }^{1} \cdot$ Anne Kasus-Jacobi ${ }^{1,2} \cdot$ Megan Lerner $^{3} \cdot$ Sreemathi Logan $^{4}$. \\ Adekunle M. Adesina ${ }^{7}$ H. Anne Pereira ${ }^{1,2,5,6}$
}

Accepted: 29 June 2015 / Published online: 14 July 2015

(C) The Author(s) 2015. This article is published with open access at Springerlink.com

\begin{abstract}
Inflammation is a well-defined factor in Alzheimer's disease (AD). There is a strong need to identify the molecules contributing to neuroinflammation so that therapies can be designed to prevent immune-mediated neurotoxicity. The cationic antimicrobial protein of $37 \mathrm{kDa}$ (CAP37) is an inflammatory mediator constitutively expressed in neutrophils (PMNs). In addition to antibiotic activity, CAP37 exerts immunomodulatory effects on microglia. We hypothesize that CAP37 mediates the neuroinflammation associated with $\mathrm{AD}$. However, PMNs are not customarily associated with the pathology of AD. This study was therefore designed to identify non-neutrophilic
\end{abstract}

H. Anne Pereira

Anne-Pereira@ouhsc.edu

1 Oklahoma Center for Neuroscience, University of Oklahoma Health Sciences Center, 1110 N. Stonewall Ave., CPB 255, Oklahoma City, OK 73117, USA

2 Department of Pharmaceutical Sciences, University of Oklahoma Health Sciences Center, 1110 N. Stonewall Ave., CPB 255, Oklahoma City, OK 73117, USA

3 Department of Surgery, University of Oklahoma Health Sciences Center, 1122 NE 13th St., ORB 350, Oklahoma City, OK 73117, USA

4 Department of Geriatrics, University of Oklahoma Health Sciences Center, 975 NE 10th St., BRC 1303, Oklahoma City, OK 73104, USA

5 Department of Cell Biology, University of Oklahoma Health Sciences Center, 1110 N. Stonewall Ave., CPB 329, Oklahoma City, OK, USA

6 Department of Pathology, University of Oklahoma Health Sciences Center, 1110 N. Stonewall Ave., CPB 329, Oklahoma City, OK 73117, USA

7 Department of Pathology, Baylor College of Medicine, One Baylor Plaza, Rm 286A, Houston, TX 77030, USA source(s) of CAP37 in brains of AD patients. Brain tissues from patients and age-matched controls were analyzed for CAP37 expression using immunohistochemistry (IHC). To determine factors that induce $\mathrm{CAP} 37$ in $\mathrm{AD}, \mathrm{HCN}-1 \mathrm{~A}$ primary human neurons were treated with tumor necrosis factor-alpha (TNF- $\alpha$ ) or amyloid $\beta_{1-40}(\mathrm{~A} \beta)$ and analyzed by IHC. Western blotting and quantitative reverse transcription polymerase chain reaction (qRT-PCR) were used to confirm CAP37 expression in neurons and brain tissues. IHC revealed CAP37 in cortical neurons in temporal and parietal lobes as well as CA3 and CA4 hippocampal neurons in patients with $\mathrm{AD}$. CAP37 was found in more neurons in $\mathrm{AD}$ patients compared with age-matched controls. qRTPCR and Western blotting showed an increase in CAP37 transcript and protein in the $\mathrm{AD}$ temporal lobe, a brain region that is highly impacted in AD. qRT-PCR observations confirmed CAP37 expression in neurons. TNF- $\alpha$ and $A \beta$ increased neuronal expression of CAP37. These findings support our hypothesis that neuronal CAP37 may modulate the neuroinflammatory response in $\mathrm{AD}$.

Keywords Neuroinflammation · CAP37 - Alzheimer's disease $\cdot$ Neurons $\cdot$ Amyloid-beta $\cdot$ Microglia

$\begin{array}{ll}\text { Abbreviations } \\ \text { AD } & \text { Alzheimer's disease } \\ \text { CAP37 } & \text { Cationic antimicrobial protein of } 37 \mathrm{kDa} \\ \text { PMN } & \text { Polymorphonuclear leukocyte } \\ \text { IHC } & \text { Immunohistochemistry } \\ \text { TNF- } \alpha & \text { Tumor necrosis factor-alpha } \\ \text { A } \beta & \text { Amyloid-beta } \\ \text { qRT-PCR } & \text { Quantitative reverse transcription polymerase } \\ & \text { chain reaction } \\ \text { PKC } & \text { Protein kinase C } \\ \text { LPS } & \text { Lipopolysaccharide }\end{array}$




\begin{tabular}{|c|c|}
\hline CNS & Central nervous system \\
\hline CERAD & $\begin{array}{l}\text { Consortium to establish a registry for Alzhei- } \\
\text { mer's disease }\end{array}$ \\
\hline DMEM & Dulbecco's modified Eagle's medium \\
\hline ATCC & American type culture collection \\
\hline HRP & Horseradish peroxidase \\
\hline GAPDH & Glyceraldehyde dehydrogenase \\
\hline $\mathrm{BCA}$ & Bicinchoninic acid \\
\hline TBST & Tris-buffered saline with Tween \\
\hline ECL & Enhanced chemiluminescence \\
\hline CA & Cornu Ammonis \\
\hline CSF & Cerebrospinal fluid \\
\hline AMP & Antimicrobial peptide \\
\hline NO & Nitric oxide \\
\hline ROS & Reactive oxygen species \\
\hline
\end{tabular}

\section{Introduction}

The cationic antimicrobial protein of molecular weight $37 \mathrm{kDa}$ (CAP37) is an inflammatory mediator expressed constitutively in the azurophil granules of polymorphonuclear neutrophils (PMNs), and is considered an important component of the innate immune system (Pereira et al. 1990a; Griffith et al. 2013). Previous findings have shown increased CAP37 levels during inflammatory conditions such as sepsis and atherosclerosis (Lee et al. 2002; Pereira et al. 2003; Linder et al. 2009). CAP37 has potent antimicrobial activity (Pereira et al. 1993, 1995, 2006) and also exerts various regulatory functions in mammalian cells. Some of these functions include activation of protein kinase $\mathrm{C}$ (PKC) and upregulation of adhesion proteins on endothelial cells and corneal epithelial cells; contraction of endothelial cells; proliferation of smooth muscle cells; corneal epithelial wound healing; and chemotaxis of monocytes, microglia, smooth muscle cells, and corneal epithelial cells (Pereira et al. 1990a, 2003, 2004; Gautam et al. 2001; Gonzalez et al. 2004; Griffith et al. 2014).

CAP37 is induced in corneal epithelial cells, endothelial cells, and smooth muscle cells in response to cytokines, lipopolysaccharide (LPS), and infection (Pereira et al. 1996b; Lee et al. 2002; Ruan et al. 2002; Gonzalez et al. 2004). In addition, CAP37 expression has been found in endothelial cells of hippocampal vasculature in patients with Alzheimer's disease (AD), while this expression was absent in age-matched controls (Pereira et al. 1996a). This finding is important, as the hippocampus is responsible for memory formation and is one of the main regions where AD pathology first manifests (Pereira et al. 1996a). Although CAP37 shares $\sim 45, \sim 42$, and $\sim 32 \%$ sequence homology with the serine proteases elastase, proteinase 3 , and cathepsin $\mathrm{G}$, respectively, CAP37 itself lacks serine protease activity due to the loss of 2 of 3 conserved residues of the catalytic triad (Pereira et al. 1990b). Elastase and proteinase-3 have been observed in various regions of the brain, including the hippocampus, cerebellum, and cerebral cortex (Davies et al. 1998), and elastase has been detected in murine microglial cells (Nakajima et al. 1992). However, the exact cell expression profile of these other proteases in the human brain is unknown. Expression of human $\beta$-defensin-1, another cationic antimicrobial peptide, has been reported within brain hippocampal astrocytes, neurons, and the choroid plexus and was increased in these regions in patients with $\mathrm{AD}$ (Williams et al. 2013). The role of these proteins in AD is unknown. However, since all are involved in innate immunity and defense, their expression in brain cells raises the question of whether any of these proteins might have a role in the low-grade chronic inflammatory response that occurs in neurodegenerative diseases such as $\mathrm{AD}$ (Wilson et al. 2002; Heneka et al. 2010; Hensley 2010; Grammas 2011; Eikelenboom et al. 2012).

A primary research focus of our laboratory is defining the mechanisms whereby CAP37 modulates neuroinflammation. As CAP37 is a potent activator of microglia, we hypothesized that CAP37 expressed within the brain parenchyma was one of the mediators of neuroinflammation in Alzheimer's disease. Thus, in this study, we aimed to determine the CAP37 cellular expression and localization in brains from patients with Alzheimer's disease. Our results indicate that CAP37 is expressed in neutrophils, the vascular endothelium, and neurons in specific brain regions from patients with AD. CAP37 transcript and protein levels are increased in patients with $\mathrm{AD}$, and primary neurons can be induced to express CAP37 in response to tumor necrosis factor-alpha (TNF- $\alpha)$ and amyloid-beta $(\mathrm{A} \beta)$.

\section{Materials and methods}

\section{Tissue specimens}

Tissues from nine patients diagnosed with $\mathrm{AD}$ and nine respective age-matched controls were kindly provided by Dr. Eileen Bigio of the Department of Pathology, Northwestern University Feinberg School of Medicine, Alzheimer's Disease Center, Neuropathology Core. All patients and age-matched controls were characterized for $\mathrm{AD}$ pathology using the Consortium to Establish a Registry for Alzheimer's Disease (CERAD) plaque grades (A-C) and Braak tangles stages (I-VI) to determine the approximate disease stage. All AD tissue specimens used for IHC were given CERAD scores of $\mathrm{C}$ and Braak \& Braak stage $\mathrm{VI}$ for tangles. Age-matched controls were given CERAD 
scores of A, B, or 0, and were Braak \& Braak stages I-III or 0 .

\section{Cell culture and treatment of $\mathrm{HCN}-1 \mathrm{~A}$ neurons}

We purchased $\mathrm{HCN}-1 \mathrm{~A}$, primary human cortical neuronal cells, from American Type Culture Collection (ATCC, Manassas, VA). Dulbecco's modified Eagle's medium (DMEM, ATCC) supplemented with $20 \%$ bovine calf serum, $1 \%$ antibiotic-antimycotic, and $1 \%$ L-glutamine (Life Technologies, Grand Island, NY) was used to culture $\mathrm{HCN}-1 \mathrm{~A}$ cells according to the ATCC recommendations. The HCN-1A cells were used in immunohistochemistry. During the course of our studies, ATCC discontinued the distribution of $\mathrm{HCN}-1 \mathrm{~A}$ cells due to quick senescence of the cells and insufficient inventory. The HCN-1A cells were thus unavailable for use in other assays. $\mathrm{HCN}-1 \mathrm{~A}$ cells were treated overnight $(17 \mathrm{~h})$ with either the 40 amino acid $\mathrm{A} \beta$ peptide $\left(\mathrm{A} \beta_{1-40}\right.$, Bachem, Torrance, $\mathrm{CA}$, stock solution in ultrapure water) at a concentration of $125 \mu \mathrm{g} / \mathrm{ml}$ or human recombinant tumor necrosis factor-alpha (TNF- $\alpha$, Roche, Indianapolis, IN) at a concentration of $25 \mathrm{ng} / \mathrm{ml}$. Control treatments included HCN-1A incubation with either inactive (reverse peptide order) $A \beta$ peptide $\left(A \beta_{40-1}\right)$ (Bachem, stock solution in $10 \%$ acetic acid) or vehicle alone (basal medium or basal medium containing an equivalent volume of $10 \%$ acetic acid). $A \beta$ was diluted in basal medium and incubated for $2 \mathrm{~h}$ at room temperature before administration, to allow the formation of toxic oligomers and fibrillar aggregates that are found in $\mathrm{AD}$.

\section{Antisera}

We used $7 \mu \mathrm{g} / \mathrm{ml}$ rabbit anti-CAP37 antiserum as described previously (Pereira et al. 1996a), a control of $7 \mu \mathrm{g} / \mathrm{ml}$ normal rabbit antiserum (Jackson ImmunoResearch Laboratories, West Grove, PA), an in-house made mouse monoclonal antibody to CAP37 (D5F10), and a mouse IgG1 isotype antibody was used as a control (Sigma-Aldrich, St. Louis, MO). D5F10 and the isotype control were diluted in Emerald antibody diluent (Cell Marque, Rocklin, CA) to a concentration of $4 \mu \mathrm{g} / \mathrm{ml}$ for IHC and were diluted in $2 \%$ bovine serum albumin (BSA, Calbiochem, Billerica, MA) in Tris-buffered saline with $0.05 \%$ Tween (TBST) blocking solution to a concentration of $0.2 \mu \mathrm{g} / \mathrm{ml}$ for Western blots. Rabbit polyclonal anti-A $\beta$ (Cell Signaling, Danvers, MA) and rabbit polyclonal anti-phospho-tau (Santa Cruz, Dallas, TX) were diluted in Emerald antibody diluent to a concentration of $10 \mu \mathrm{g} / \mathrm{ml}$ to detect $\mathrm{A} \beta$ plaques and tau tangles, respectively. A rabbit IgG antibody was employed as an isotype control (Cell Signaling, Danvers, MA). We also used the following secondary antibodies: horseradish peroxidase (HRP)-conjugated donkey anti-mouse and donkey anti-rabbit IgGs diluted in TBST to concentrations of $0.04 \mu \mathrm{g} / \mathrm{ml}$ (Jackson ImmunoResearch Laboratories, West Grove, PA).

\section{Immunocytochemistry}

HCN-1A cells were evenly seeded into 4-well LAB-TEK tissue culture chambers (NUNC, Inc., Naperville, IL) and incubated until confluency. Cells were then treated with either $\mathrm{A} \beta_{1-40}$, TNF- $\alpha$, or serum-free DMEM as described above. Following treatment, cells were fixed with formol acetone and stained using the Vectastain $\mathrm{ABC}$ peroxidase system (Vector Laboratories, Burlingame, CA) as previously described (Pereira et al. 1996a). The rabbit antiCAP37 and normal rabbit serum were added for $17 \mathrm{~h}$. Images of stained neurons were taken at 400X magnification (Nikon TE2000, Nikon Instruments Inc., Melville, NY). Figures were created using Microsoft PowerPoint 2010.

\section{Immunohistochemistry}

Formalin-fixed, paraffin-embedded brain tissues from patients with Alzheimer's disease and age-matched controls were sectioned at a thickness of $5 \mu \mathrm{m}$. Sections were incubated in antigen retrieval solution (Tris buffer, $\mathrm{pH}$ 9) for $20 \mathrm{~min}$ in a rice steamer, followed by a 20-min cool down in distilled water. Staining was performed using reagents from the HiDef HRP kit (Cell Marque) according to the manufacturer's instructions. Tissues were incubated with mouse anti-CAP37 $(4 \mu \mathrm{g} / \mathrm{ml})$ or the equivalent amount of mouse IgG1 isotype control for $60 \mathrm{~min}$. Color was developed with 3,3'-diaminobenzidine (Cell Marque), and sections were counterstained with hematoxylin (American Master Tech, Lodi, CA). Images were examined, and photographs were taken using bright-field microscopy at $400 \mathrm{X}$ and $1000 \mathrm{X}$ magnifications (Nikon eclipse E200, Nikon Instruments Inc., Melville, NY). Figures were created using Microsoft PowerPoint 2010.

\section{Quantitative RT-PCR}

Total RNA from primary human neurons and primary human astrocytes (Sciencell, Carlsbad, CA) and total RNA from temporal, frontal, and occipital lobe tissues of patients with $\mathrm{AD}$ and five donor pool normal controls (Biochain, Newark, CA) were purchased from their respective commercial vendors. AD patients included a 73-year-old male (frontal lobe RNA), 77-year-old male (occipital lobe RNA), 80-year-old male (temporal and frontal lobe RNA), 83-year-old male (temporal lobe RNA), 85-year-old female 
(occipital lobe RNA), and an 87-year-old male (temporal, frontal, and occipital lobe RNA) for a total of six patients analyzed with three utilized for each brain region. Pooled controls were all from males with ages ranging from 20 to 44 years. PCR-ready first-strand cDNA from peripheral blood leukocytes was obtained from Biochain. PCR-ready first-strand cDNA from human microglia was obtained from Sciencell. Primary neuron RNA $(2 \mu \mathrm{g})$, primary astrocyte RNA ( $2 \mu \mathrm{g})$, AD patient RNA ( $3 \mu \mathrm{g})$, and normal control pooled RNA ( $3 \mu \mathrm{g}$ ) were converted to cDNA using the Qiagen $\mathrm{RT}^{2}$ First-Strand Kit (Qiagen Inc., Valencia, CA) in a final volume of $111 \mu \mathrm{L}$ according to the manufacturer's instructions. Amplification of cDNA was performed using $\mathrm{RT}^{2}$ SYBR Green mastermix (containing HotStart DNA Taq Polymerase), Qiagen $\mathrm{RT}^{2} \mathrm{qPCR}$ primers (GAPDH: \#PPH00150F, PRTN3: \#PPH07029A, ELANE: \#PPH01057A, AZU1: \#PPH01031A), and Solaris primers (CTSG \#AX-005838-00-0100, GAPDH\# AX-00583800-0100), following the manufacturer's instructions. For each $25-\mu \mathrm{L}$ reaction, $1 \mu \mathrm{L}$ of the prepared cDNA was mixed with $1 \mu \mathrm{L}(0.4 \mu \mathrm{M})$ of respective primer, $12.5 \mu \mathrm{L}$ of $\mathrm{RT}^{2}$ SYBR Green mastermix, and $10.5 \mu \mathrm{L}$ of RNasefree water. All reactions were performed in triplicate. PCRs were performed using the MyiQ Single Color Real-Time PCR Detection System (Bio-Rad, Hercules, CA) beginning with a denaturation step $\left(10 \mathrm{~min}\right.$ at $\left.95{ }^{\circ} \mathrm{C}\right)$ followed by 40 repeated cycles of annealing/extension: $15 \mathrm{~s}$ at $95^{\circ} \mathrm{C}$ and $1 \mathrm{~min}$ at $60{ }^{\circ} \mathrm{C}$. qRT-PCR was performed on primary neurons, primary microglia, primary astrocytes, and normal control pools twice and on AD patients and leukocytes once. The $\Delta C_{\mathrm{t}}$ values were calculated to normalize each gene expression to glyceraldehyde 3-phosphate dehydrogenase $(G A P D H)$. To calculate fold difference in mRNA expression relative to GAPDH, the equation [fold change $\left.=2^{(-\Delta C t)}\right]$ was used. Figures were created using Prism software (GraphPad Software Inc., version 6, La Jolla, CA.)

\section{Western blot analysis}

Total protein lysates from the temporal lobe of one patient with AD (75-year-old male), from the frontal lobe of one patient with AD (83-year-old male), and from the temporal (26-year-old male) and frontal (71-year-old male) lobes of normal controls were obtained from Biochain. According to the vendor, all tissues were obtained $4-6 \mathrm{~h}$ postmortem and were stored in liquid nitrogen before distribution. Human astrocyte and microglia lysates were derived from single healthy donors and obtained from Sciencell. The protein concentration of each sample was provided by the respective vendors. The protein concentration of total temporal and frontal lobe lysates was verified using the bicinchoninic acid (BCA) assay (Pierce, Rockford, IL). Purified CAP37 derived from human neutrophils (Athens Research Technology, Athens, Georgia) was also run as a marker for CAP37 migration. Total lysates from human astrocytes, human microglia, temporal lobes, frontal lobes $(40 \mu \mathrm{g})$, PMNs (50 ng), and purified CAP37 (5 ng) were separated by a $12.5 \%$ SDS-PAGE gel. Proteins were transferred to a nitrocellulose membrane (Whatman, Pittsburgh, PA) overnight, and the membranes were blocked in $2 \%$ BSA in TBST. Membranes were probed with either mouse monoclonal anti-CAP37 $(0.2 \mu \mathrm{g} / \mathrm{ml})$ or the equivalent amount of mouse isotype control overnight at $4{ }^{\circ} \mathrm{C}$. Blots were incubated with HRP-conjugated donkey anti-mouse secondary antibody $(0.04 \mu \mathrm{g} / \mathrm{ml}$; Jackson Laboratories) for $1 \mathrm{~h}$ at room temperature. Enhanced chemiluminescence (ECL) substrates (Pierce, Rockford, IL) were used to develop all blots. ImageJ software (National Institutes of Health [NIH], Bethesda, MD) was used to quantify mean band density. Figures were created using Microsoft PowerPoint 2010.

\section{Statistical analysis}

Statistical analysis was performed using Prism software. Student's unpaired $t$ tests were used to analyze the AZU1, ELANE, and PRTN3 mRNA expressions of individual patients with AD relative to the normal control pools. The mRNA expression values were calculated as described in the above methods and are represented as mean \pm SEM, and $p<0.05$ was considered statistically significant.

\section{Results}

\section{Both parietal and temporal lobes from AD patients express CAP37}

CAP37 expression in the endothelial cells lining vessels of the hippocampus in patients with $\mathrm{AD}$ has been previously demonstrated (Pereira et al. 1996a). However, whether CAP37 was also expressed in additional brain regions from $\mathrm{AD}$ patients has not been studied. Therefore, parietal and temporal lobe tissues from patients with $\mathrm{AD}(n=9)$ or age-matched normal controls $(n=9)$ were evaluated for CAP37 expression. Performing IHC using a novel monoclonal antibody specific for CAP37 detected expression of this immune modulator in the polymorphonuclear leukocytes (PMNs) and endothelial cells in both the parietal (Fig. 1a) and temporal lobes (Fig. 1b) of all AD patients and age-matched controls (Fig. 1e, f). Staining with isotype control antibody failed to detect PMNs and endothelial cells, indicating the 
Fig. 1 CAP37 is expressed in neutrophils and endothelial cells of parietal and temporal cortices. a Parietal lobe and $\mathbf{b}$ temporal lobe cortical tissues from an Alzheimer's disease (AD) patient stained with antiCAP37. c Parietal lobe and d temporal lobe cortical tissues from an $\mathrm{AD}$ patient stained with isotype control. e Parietal lobe and $\mathbf{f}$ temporal lobe cortical tissues from an age-matched control stained with antiCAP37. g Parietal lobe and $\mathbf{h}$ temporal lobe cortical tissues from an age-matched control stained with isotype control. Neutrophils are indicated by arrowheads, and endothelial cells are represented by arrows. Scale bars $20 \mu \mathrm{m}$
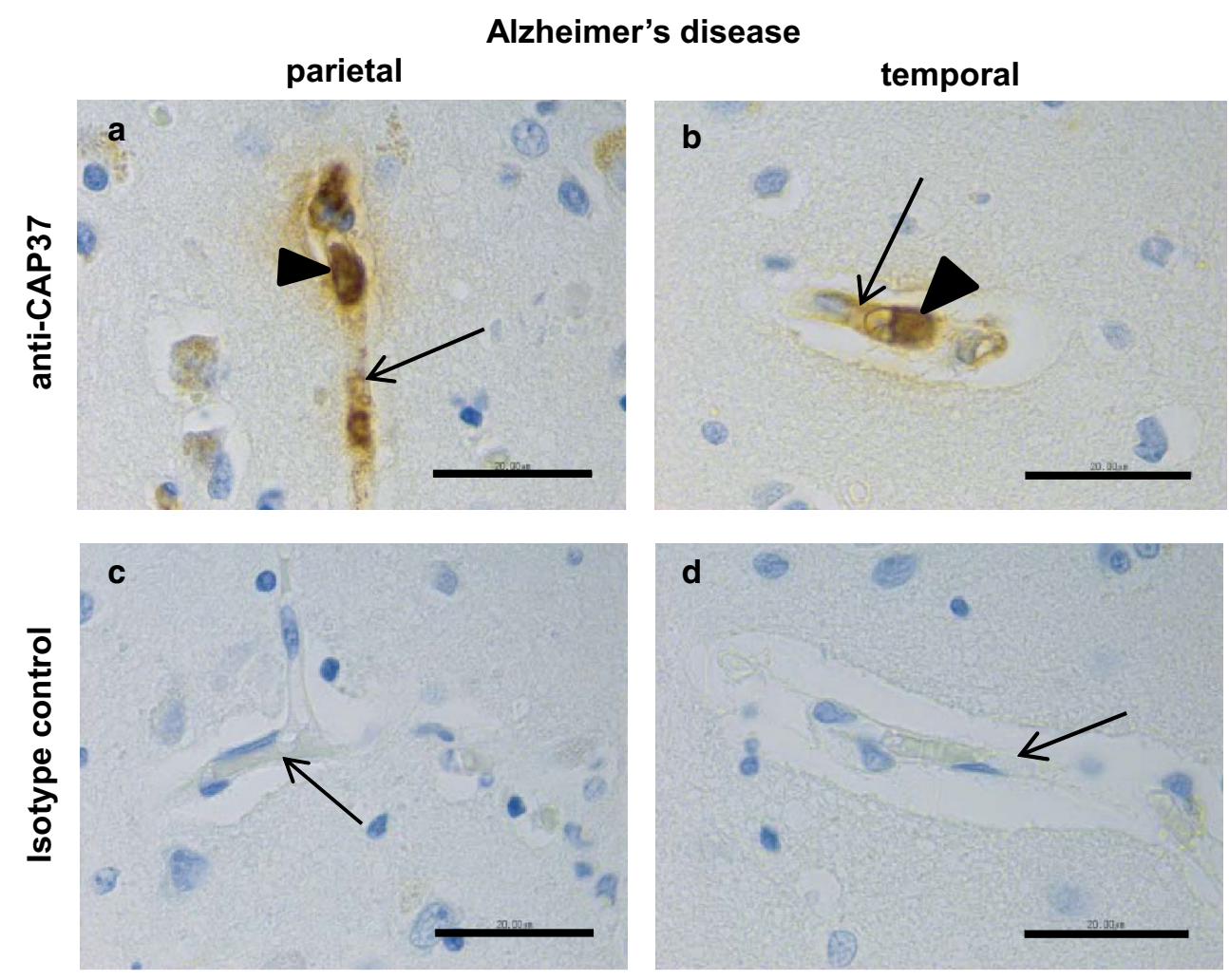

\section{Age-matched controls}
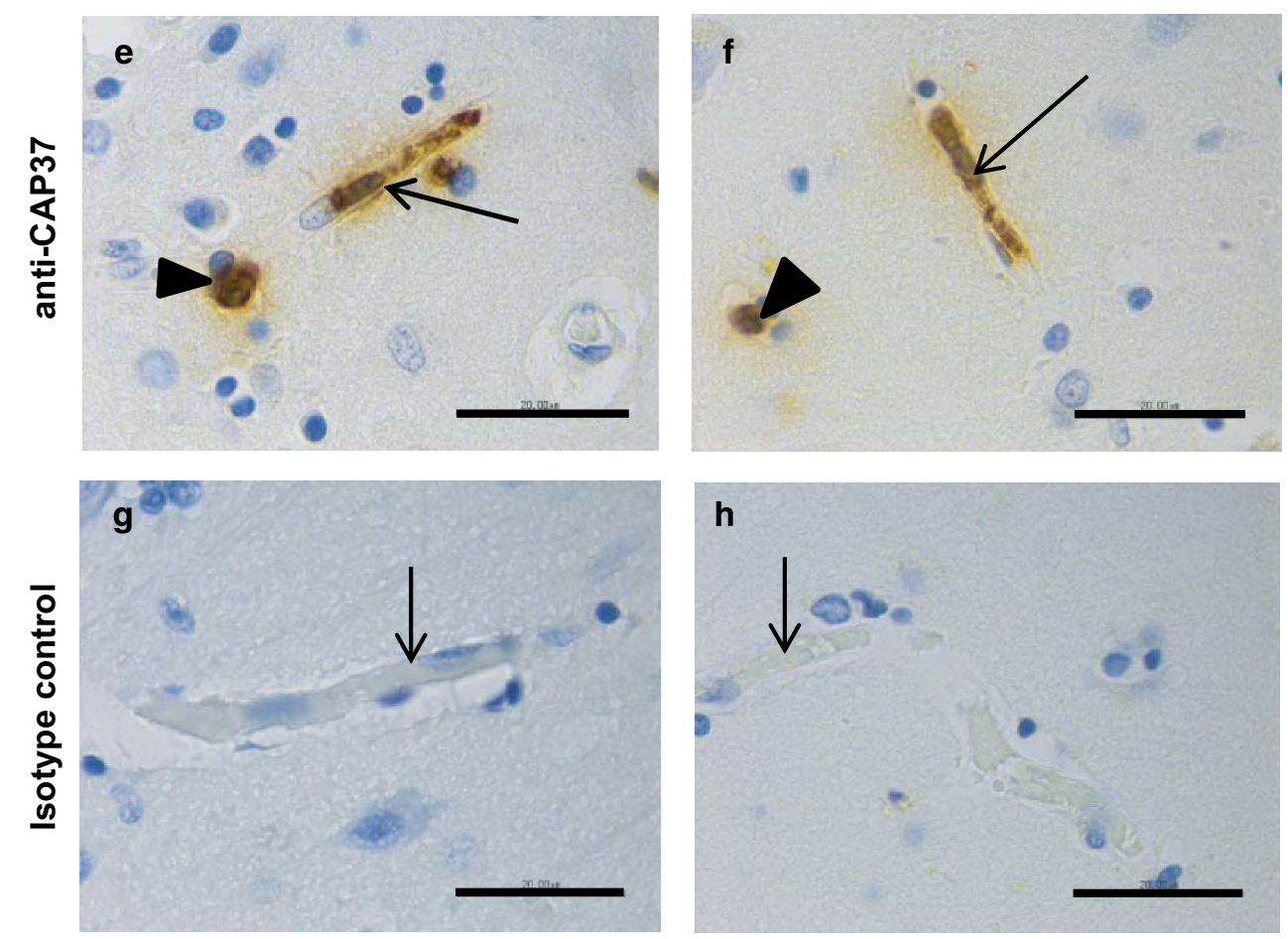

specificity of staining for CAP37 in these two cell types (Fig. 1c, d, g, h). These assays confirmed the applicability of this monoclonal antibody for use in IHC on brain tissues since CAP37 is constitutively expressed in neutrophils and is also expressed in endothelial cells from other tissues. 
Fig. 2 Temporal cortical neurons have increased CAP37 expression during $\mathrm{AD}$. ai $\mathrm{AD}$ temporal cortical lobe tissue stained with monoclonal antiCAP37 showing strong staining in the AD neuron cell bodies. CAP37 staining varied from localized staining in pyramidal layers 3 and 5 to a diffuse cortical distribution. bi AD temporal cortical lobe tissue stained with isotype control. ci Agematched control brain stained with monoclonal anti-CAP37. Note the reduced staining in the neuron cell bodies. aii, bii, cii Lower magnification images of respective sections. Asterisks (*) with pointing arrows indicate microglial cells that lack CAP37. Scale bars ai, bi, and ci, $20 \mu \mathrm{m}$; aii, bii, and cii, $50 \mu \mathrm{m}$
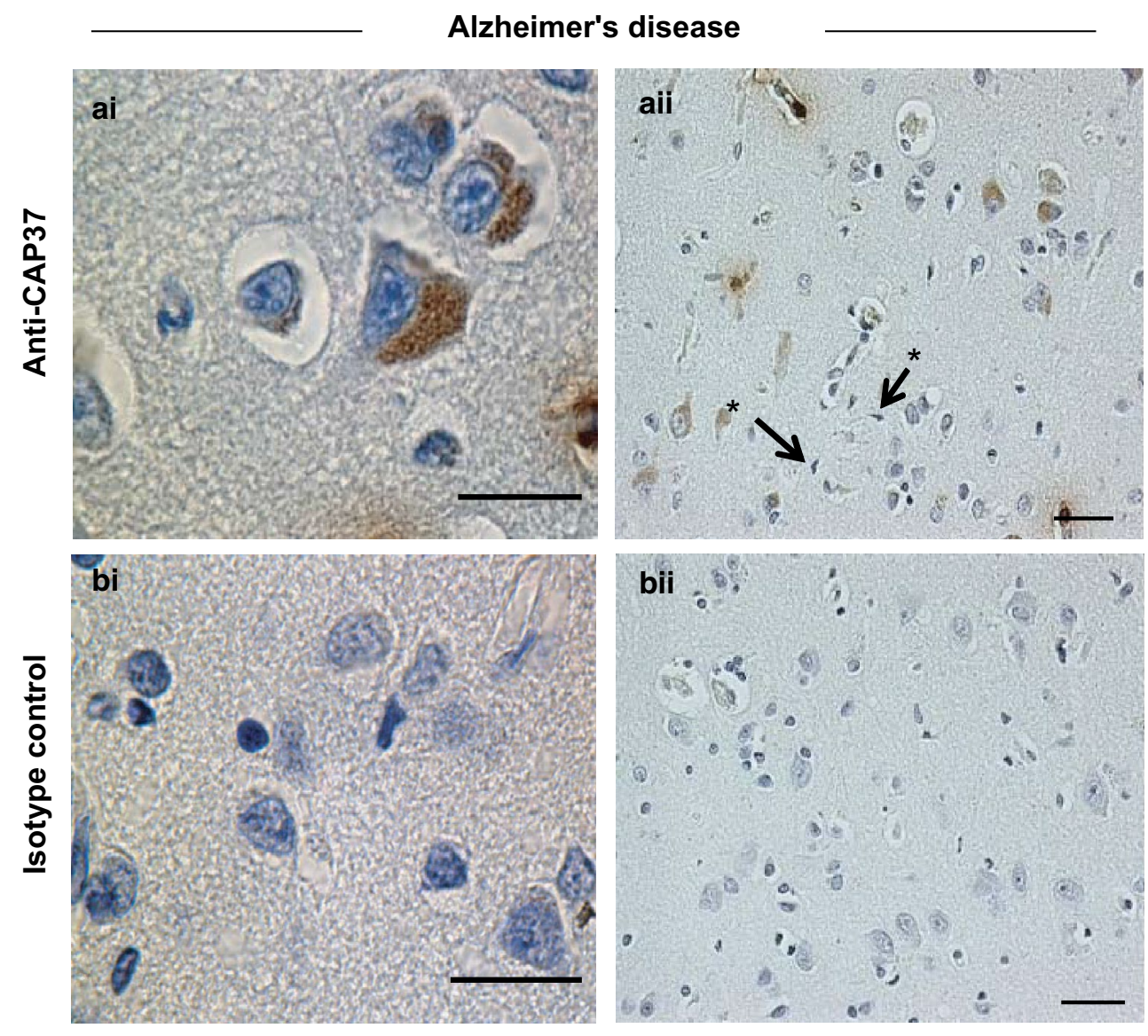

Age-matched controls

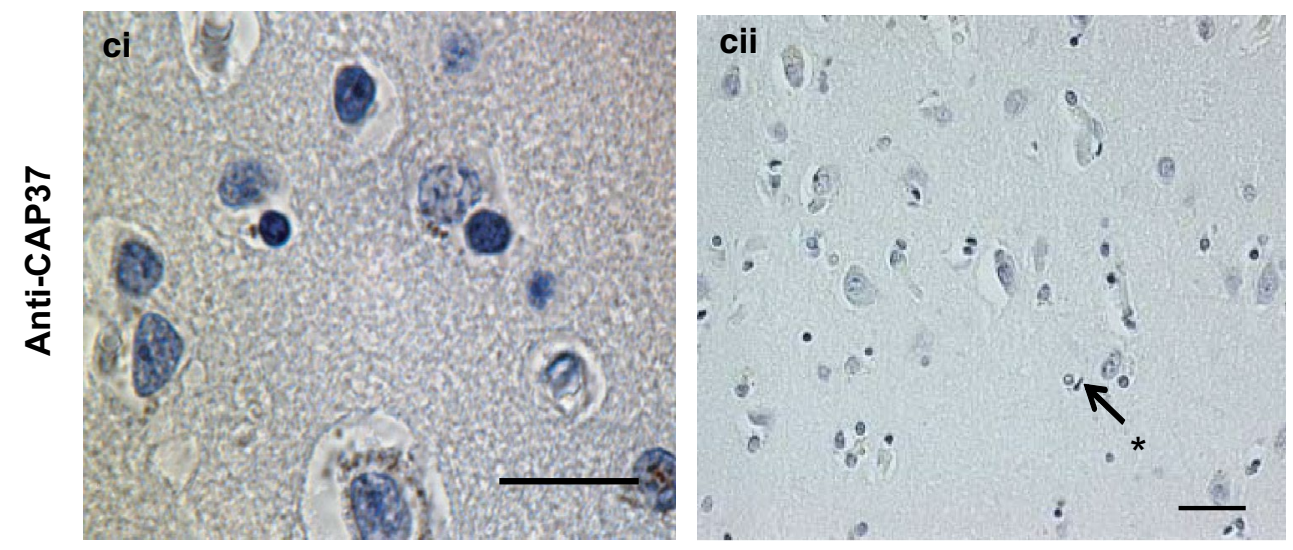

\section{Cortical pyramidal neurons in temporal and parietal lobes are a novel cellular source of CAP37 expression and are a site of CAP37 upregulation in AD patients}

The temporal and parietal lobes of AD patients were then evaluated to identify additional CAP37 cellular sources. CAP37 was detected in the cytoplasm of cortical neurons in the temporal lobes of patients with AD (Fig. 2ai, aii). The pattern of CAP37 staining varied from localized in pyramidal layers 3 and 5 to a diffuse cortical distribution.
We observed a predominant limitation to pyramidal layers 3 and 5 more often than a diffuse cortical pattern. However, a diffuse pattern was often associated with a more intense cytoplasmic staining on a per-patient basis. No temporal lobe staining was observed with the isotype control (Fig. 2bi, bii), indicating the CAP37 staining specificity in PMNs, endothelial cells, and neurons. CAP37 was observed in temporal lobe pyramidal layers 3 and 5 in some control subjects as well. However, fewer neurons were CAP37-positive in control tissues (Fig. 2ci, cii) than in 
Fig. 3 Parietal cortical neurons have increased CAP37 expression during $\mathrm{AD}$. ai $\mathrm{AD}$ cortical brain tissue from parietal lobes stained with monoclonal antiCAP37. Intense CAP37 staining is localized to the AD neuron cell bodies. CAP37 appeared in pyramidal layers 3 and 5 in some patients and showed a more diffuse cortical distribution in others bi AD parietal lobe tissues stained with isotype control. ci Age-matched control brain stained with monoclonal anti-CAP37 IgG. aii, bii, cii Lower magnification images of respective sections. Asterisks (*) with pointing arrows indicate microglial cells that lack CAP37. Scale bars ai, bi, and ci, $20 \mu \mathrm{m}$; aii, bii, cii, $50 \mu \mathrm{m}$
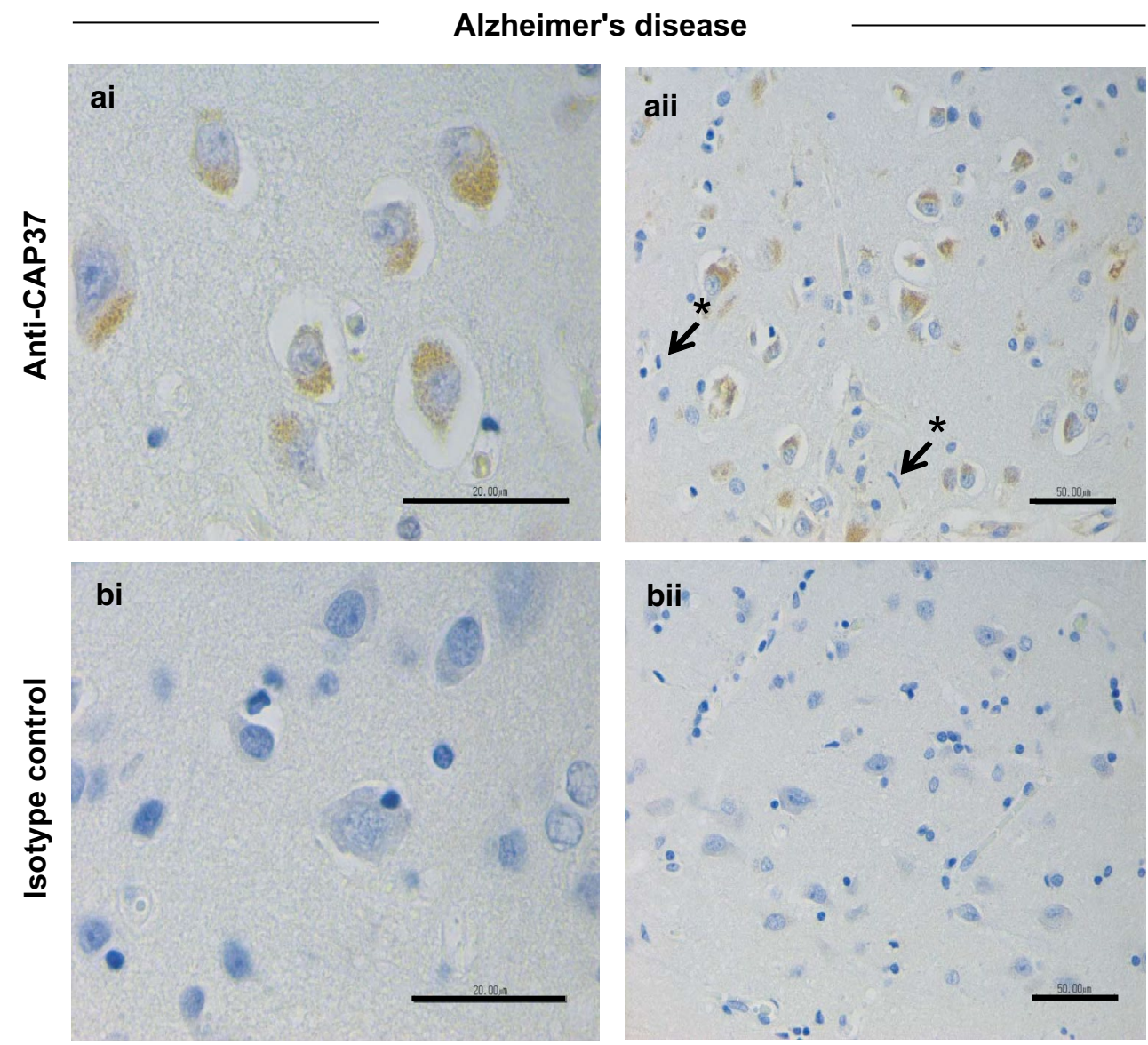

Age-matched controls

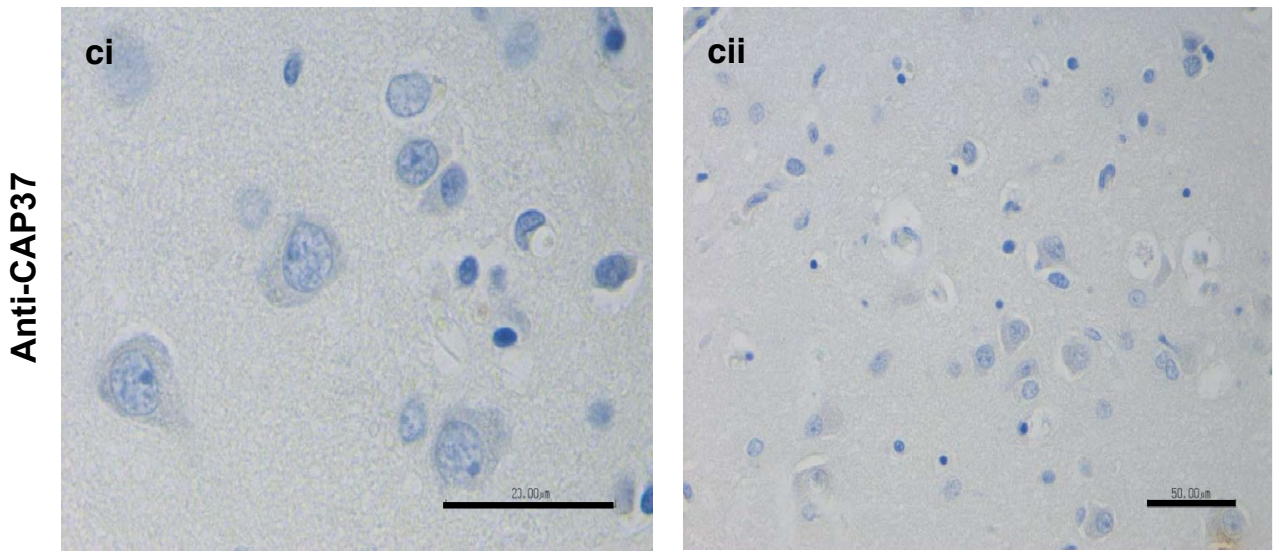

tissues from patients with dementia. No CAP37 expression was observed in glial cells, including microglia (Fig. 2aii, cii). CAP37 staining in the parietal lobes of patients with $\mathrm{AD}$ and controls showed a similar pattern to that seen in the temporal lobes. Neurons within pyramidal layers 3 and 5 of the parietal cortex from $\mathrm{AD}$ patients were also positive for CAP37 (Fig. 3ai, aii). This was not observed with the isotype control (Fig. 3bi, bii). Again, some age-matched controls showed neuronal staining for CAP37 in the parietal lobes, but fewer control neurons stained positive than did AD neurons (Fig. 3ci, cii). No glial cells stained positive for CAP37 in the parietal lobe (Fig. 3aii).

\section{CAP37 is expressed in the CA3 and CA4 hippocampal neurons}

The hippocampus was evaluated in $\mathrm{AD}$ patients using the CAP37 monoclonal antibody to determine additional 
Fig. 4 CAP37 is expressed in CA3 and CA4 hippocampal neurons. $\mathbf{a} \mathrm{AD}$ and $\mathbf{b}$ agematched control hippocampal tissue stained with anti-CAP37 showing staining in neuronal cell bodies. c AD patient and d age-matched control stained with anti-amyloid- $\beta$ showing frequent neuritic plaques in both. e AD patient and $\mathbf{f}$ agematched control stained with anti-phospho-tau (Thr 205) showing Braak stage VI tangles in patient and Braak stage II tangles in age-matched control. Scale bars $\mathbf{a}$ and $\mathbf{b}, 40 \mu \mathrm{m}$; $\mathbf{c}-\mathbf{f}$ : $50 \mu \mathrm{m}$
AD
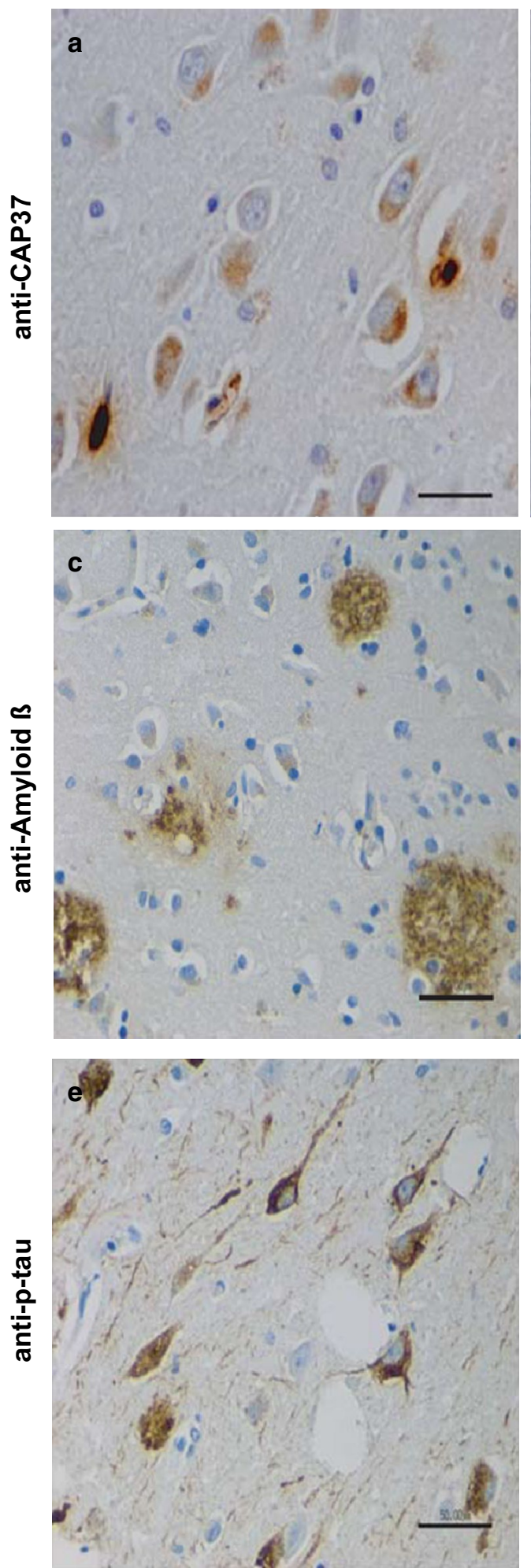

Age-matched control

(with AD pathology)
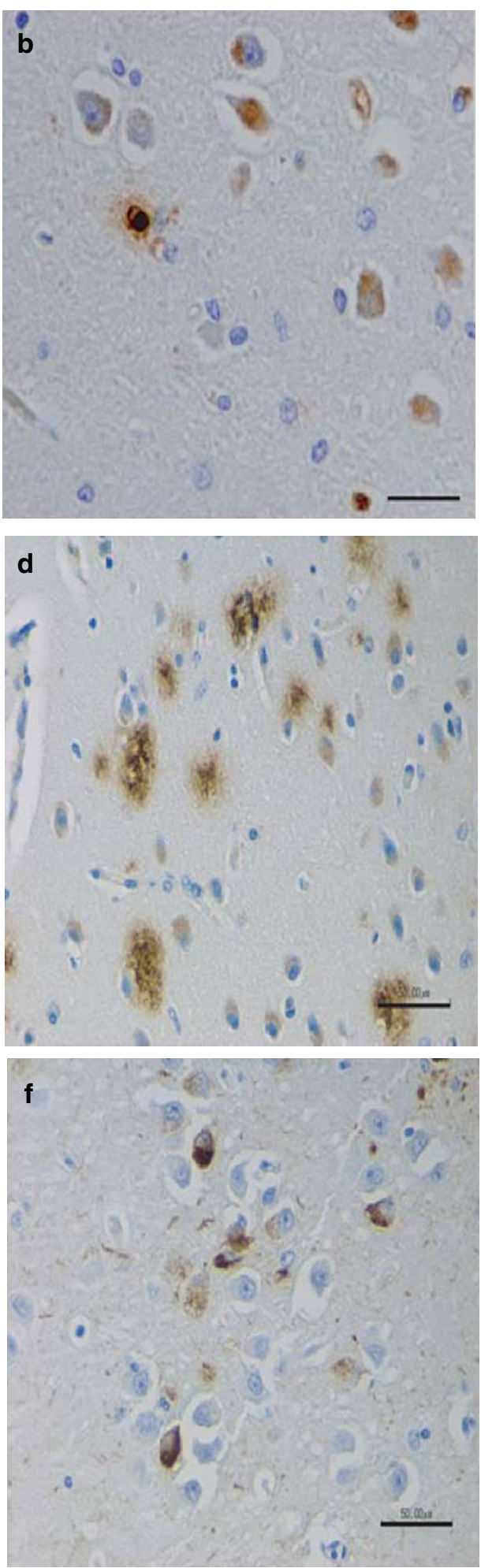

CAP37 cellular sources other than sources previously revealed. IHC analysis on hippocampal sections from three patients with AD (Fig. 4a) and age-matched controls
(Fig. 4b) revealed CAP37 expression in pyramidal neurons of the Cornu Ammonis (CA) regions 3 and 4. All three patients with $\mathrm{AD}$ were previously analyzed for $\mathrm{AD}$ 
pathology and characterized to have CERAD plaque scores of $\mathrm{C}$ and Braak and Braak stage VI for tangles. Our IHC staining also confirmed the high frequency of plaques (Fig. 4c) and tangles (Fig. 4e) in these patients. Although one of the age-matched controls showed no signs of neuritic plaques or tangles, the other two contained both plaques and tangles, with one also having frequent neuritic plaques (Fig. 4d) and Braak stage II for tangles (Fig. 4f). One agematched control was, therefore, characterized as having low AD neuropathological change, while another was characterized as displaying intermediate AD pathological change.

Next, CAP37 association with either A $\beta$ plaques or tau tangles was determined by IHC to analyze the localization patterns of CAP37, A $\beta$, and tau. Serial sections of the temporal cortex and hippocampus stained for CAP37, $\mathrm{A} \beta$, and tau revealed that both $\mathrm{A} \beta$ and tau were more heavily distributed than the sporadic neuron staining observed for CAP37. Although CAP37, A $\beta$, and tau overlapped in some regions, there did not appear to be a strong correlation in localization as some regions with CAP37 did not show tangles or plaques, and many regions with plaques and tangles did not also contain CAP37 (data not shown).

\section{TNF- $\alpha$ and $A \beta$ induced expression of CAP37 in human primary cortical neurons}

The ability of two AD mediators, TNF- $\alpha$, a pro-inflammatory cytokine, and $A \beta_{1-40}$ to induce the expression of CAP37 was tested using primary human cortical neurons (HCN-1A) as a model for induced expression. These cells are non-malignant and retain their native neuronal phenotype. They have the ability to divide more rapidly due to their derivation from a patient with unilateral megalencephaly, a low-grade proliferation and migration disorder affecting neurons. We initially examined these cells for constitutive expression of CAP37 and detected faint CAP37 expression (data not shown). Faint immunopositivity was also seen in vehicle-treated controls (Fig. 5a). HCN-1A neurons were treated with TNF- $\alpha$ and $\mathrm{A} \beta_{1-40}$. Then, CAP37 expression was determined using IHC. Both TNF- $\alpha$ and $\mathrm{A} \beta_{1-40}$ induced CAP37 expression in the neuronal cytoplasm (Fig. 5c, d). Cells treated with the inactive form of $\mathrm{A} \beta\left(\mathrm{A} \beta_{40-1}\right)$ were not induced to express CAP37 (Fig. 5b). Minimal staining was observed with $A \beta$ - and TNF- $\alpha$-treated cells probed with rabbit control serum (Fig. 5e, f), confirming the specificity of the CAP37 staining.

\section{CAP37 mRNA is expressed in neurons, astrocytes, and microglia}

The expression of CAP37 mRNA in primary human neurons, astrocytes, and microglia was analyzed using qRTPCR. AZU1 mRNA, which encodes for CAP37 protein, was detected in resting neurons, astrocytes, and microglia (Fig. 6). AZU1 expression in astrocytes, however, was very low compared to expression in neurons and microglia. ELANE (elastase) and PRTN3 (proteinase-3), two other proteins expressed abundantly in neutrophils with high sequence homology to CAP37, also showed mRNA expression in neurons, but at considerably lower levels compared with $A Z U 1$ (Fig. 6). ELANE and PRTN3 expression was comparable to $A Z U 1$ expression in astrocytes and microglia. To compare the levels of $A Z U 1$, ELANE, and PRTN3 mRNA expressed in resting neurons and glial cells relative to resting leukocytes, including PMNs, we performed qRT-PCR on leukocyte cDNA isolated from buffy coats, the blood fractions containing leukocytes and platelets. Upon calculating fold differences in mRNA relative to $G A P D H$, we detected approximately five times the amount of $A Z U 1$ mRNA, 283 times the amount of ELANE mRNA, and 65 times the amount of PRTN3 mRNA in total leukocytes compared with neurons (Fig. 6). There was $\sim 100$ times the amount of $A Z U 1$ mRNA, 500 times the amount of ELANE mRNA, and $\sim 850$ times the amount of PRNT3 mRNA in total leukocytes compared with astrocytes. We detected $\sim 2$ times the amount of AZU1 mRNA and $\sim 4$ times the amount of ELANE mRNA in leukocytes compared to microglia. Interestingly, PRTN3 expression in microglia was $\sim 4$ times higher than in total leukocytes. The $C_{t}, \Delta C_{t}$, and fold difference expression values of all transcripts are shown in Table 1.

\section{Only the temporal lobe has increased expression of both CAP37 mRNA and protein during AD}

Brain regions are differentially affected during AD progression. The temporal and frontal lobes are heavily impacted regions in $\mathrm{AD}$, while the occipital lobe is less severely impacted. If CAP37 contributes to inflammation during AD, then temporal or frontal lobes are expected to have increased expression of CAP37 versus the occipital lobe in AD patients compared to normal controls. The mRNA expression of AZU1, ELANE, and PRTN3 in these three lobes was compared in AD and normal controls. CTSG mRNA levels (cathepsin $\mathrm{G}$ ) in the temporal and frontal lobes were also compared. Cathepsin $\mathrm{G}$ was included in this analysis as this protein is expressed abundantly in neutrophils and shares homology with CAP37. Significantly increased levels of $A Z U 1$ mRNA were found in the temporal and frontal lobes of patients with AD compared with normal controls (Fig. 7a), which is consistent with these regions being heavily impacted in AD. Importantly, the mRNA levels of ELANE, PRTN3, and CTSG were unchanged in the temporal and frontal lobes of patients with $\mathrm{AD}$ compared with normal controls. No significant increase in $A Z U 1$ expression 
Fig. 5 CAP37 is induced in $\mathrm{HCN}-1 \mathrm{~A}$ primary human neurons. a HCN-1A neurons incubated with vehicle only (basal medium \pm equivalent volume of $10 \%$ acetic acid used as solvent for peptide). b HCN-

$1 \mathrm{~A}$ neurons treated with $\mathrm{A} \beta_{40-1}$ (reverse/inactive peptide) stained with rabbit anti-CAP37 serum. c HCN-1A cortical neurons treated with TNF- $\alpha$ ( $25 \mathrm{ng}$ / $\mathrm{ml}$ ) and stained with rabbit antiCAP37 serum. d HCN-1A cells treated with $\mathrm{A} \beta_{1-40}(125 \mu \mathrm{g} /$ $\mathrm{ml}$, pre-aggregated) and stained with rabbit anti-CAP37 serum. e $\mathrm{HCN}-1 \mathrm{~A}$ cortical neurons treated with TNF- $\alpha(25 \mathrm{ng} /$ $\mathrm{ml}$ ) and stained with normal rabbit control serum. f $\mathrm{HCN}-1 \mathrm{~A}$ neurons treated with $\mathrm{A} \beta_{1-40}$ (125 $\mu \mathrm{g} / \mathrm{ml}$, pre-aggregated) and stained with normal rabbit control serum. Treatments were performed overnight (17 h), and cells were stained using the Vectastain ABC peroxidase system. Scale bars $20 \mu \mathrm{m}$
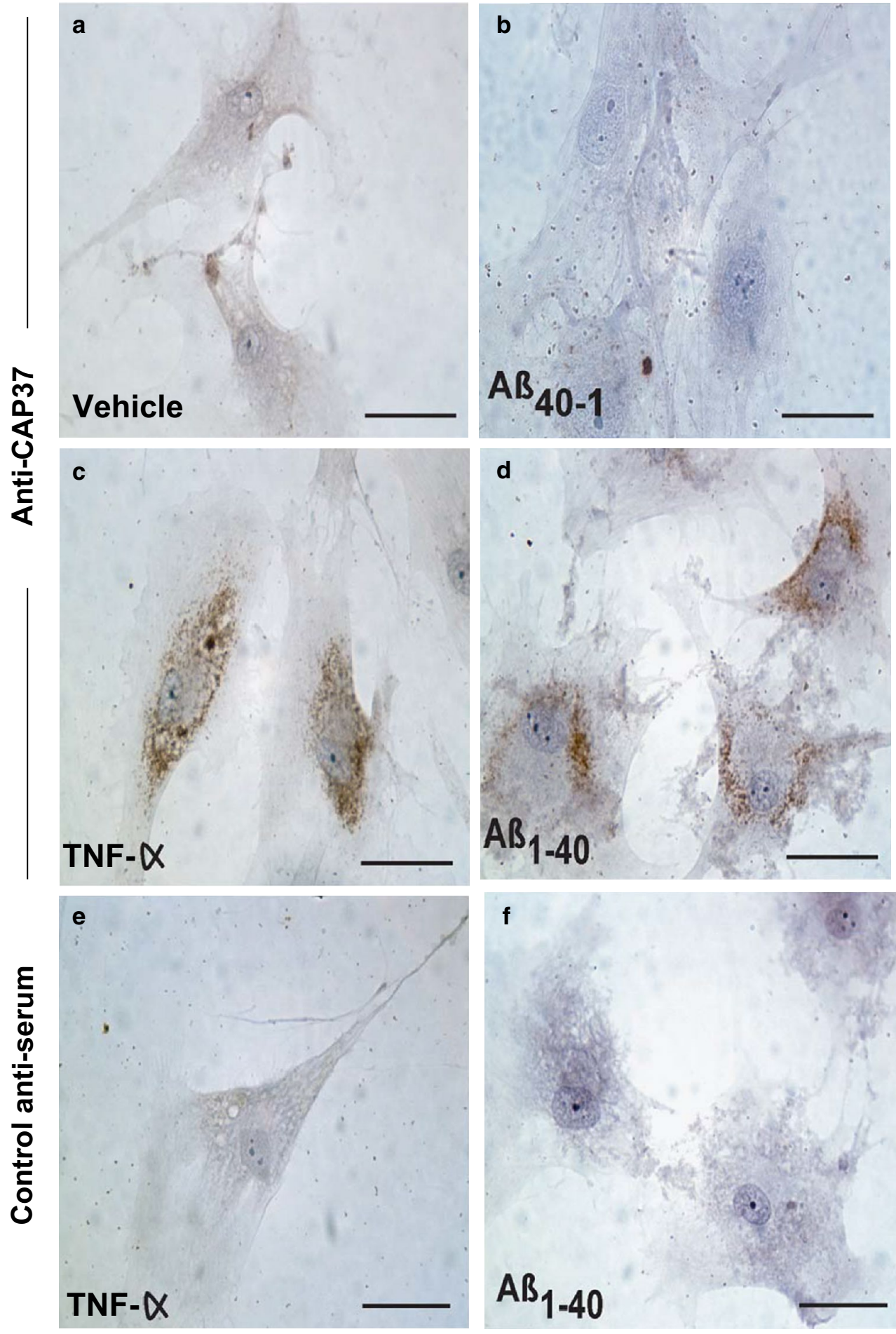

was detected in the occipital lobe, which is a region of the brain that is less severely impacted in AD. Interestingly, PRTN3 mRNA expression was significantly decreased in the occipital lobe of the brain with AD (Fig. 7a). Neither the cause nor the consequence of this decrease is known. Comparing the mRNA levels of AZU1, ELANE, PRTN3, and $C T S G$ in five donor pools of normal controls, we found that levels of AZU1 and CTSG were 5-35 times lower than the levels of ELANE and PRTN3 in all brain regions analyzed (Fig. 7b). As noted in the methods section, all mRNA values were normalized to GAPDH expression.

CAP37 protein expression in the temporal and frontal lobes of patients with AD and normal controls was analyzed by Western blot to confirm transcript expression analysis. 


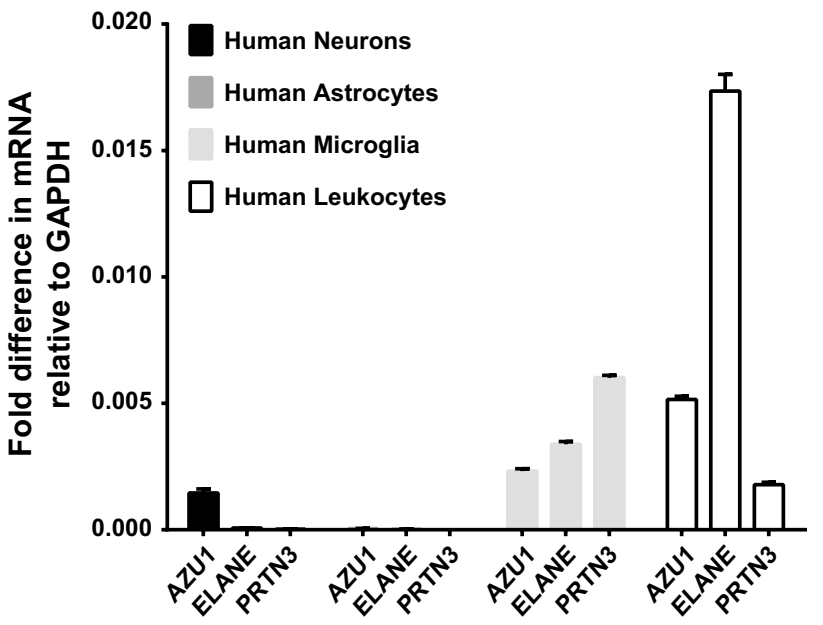

Fig. 6 CAP37 mRNA is expressed in human primary neurons, astrocytes, microglia, and leukocytes. AZU1, ELANE, and PRTN3 (encode for CAP37, elastase, and proteinase-3 proteins, respectively) mRNA expression in neurons (black bars), astrocytes (gray bars), microglia (light gray bars), and leukocytes (open bars) was determined using qRT-PCR. All values were normalized to GAPDH (internal control), and results are expressed as fold differences in mRNAs relative to GAPDH $\left(2^{(-\Delta C T)}\right)$. Analysis of AZU1, ELANE, and PRTN3 neuronal and glial expression was performed in triplicate, and leukocyte expression was performed in duplicate. Data are mean \pm SEM of results

Total lysates from the temporal and frontal lobes showed low levels of CAP37 expression in normal controls (Fig. 8ai, bi, lane 1) as determined by the detection of an approximately
29-kDa band when blots were probed with monoclonal antiCAP37. This is the same molecular weight to which the isolated native CAP37 migrated (Fig. 8ai, bi, lane 4). The tissues from the patient with AD demonstrated a band of increased intensity in the temporal lobe lysate that was absent in the normal control (Fig. 8ai, lane 1,2). This result confirms qRTPCR and IHC results showing an increase in CAP37 expression in the temporal lobe of AD patients. We observed no difference in the intensity of the 29-kDa CAP37 band in the frontal lobe normal control or AD lysates (Fig. 8bi, lanes 1, 2). However, the extract from the frontal lobe of the patient with $\mathrm{AD}$ demonstrated a band of high intensity migrating at a molecular weight of $\sim 15 \mathrm{kDa}$ (Fig. 8bi, lane 2). This was not observed in the normal control (Fig. 8bi, lane 1). Blots were also probed with mouse isotype control which showed no corresponding bands at 29 or $15 \mathrm{kDa}$ for the total lysates or purified CAP37 (Fig. 8aii, bii, lanes 1, 2, 4).

\section{CAP37 protein is not detected in astrocytes or microglia by Western blotting}

Since we observed CAP37 transcript in astrocytes and microglia, but did not observe CAP37 protein in these cells by IHC analysis of brain sections, we performed Western blotting on proteins extracted from astrocytes and microglial cells. No band corresponding to the CAP37 molecular weight was detected in astrocytes or microglia (Fig. 9, lanes 1,2). Purified native CAP37, PMN lysate, and total lysates

Table 1 Expression of $A Z U 1, E L A N E$, and PRTN3 transcripts in primary human neurons, astrocytes, microglia, and leukocytes

\begin{tabular}{|c|c|c|c|c|c|c|c|c|c|c|}
\hline & \multirow{2}{*}{$\begin{array}{l}\text { GAPDH } \\
\text { Mean } C_{\mathrm{t}}\end{array}$} & \multicolumn{3}{|l|}{ AZU1 } & \multicolumn{3}{|c|}{ ELANE } & \multicolumn{3}{|c|}{ PRTN3 } \\
\hline & & $C_{\mathrm{t}}$ & $\Delta C_{\mathrm{t}}$ & $2^{(-\Delta C t)}$ & $C_{\mathrm{t}}$ & $\Delta C_{\mathrm{t}}$ & $2^{(-\Delta C t)}$ & $C_{\mathrm{t}}$ & $\Delta C_{\mathrm{t}}$ & $2^{(-\Delta C t)}$ \\
\hline \multirow[t]{2}{*}{$\mathrm{HN}$} & 17.95 & $\begin{array}{l}27.83 \\
27.19 \\
27.05\end{array}$ & $\begin{array}{l}9.88 \\
9.24 \\
9.10\end{array}$ & $\begin{array}{l}0.00106 \\
0.00165 \\
0.00182\end{array}$ & $\begin{array}{l}31.19 \\
32.03 \\
32.04\end{array}$ & $\begin{array}{l}13.24 \\
14.08 \\
14.09\end{array}$ & $\begin{array}{l}0.00010 \\
5.7742 \times 10^{-5} \\
5.7344 \times 10^{-5}\end{array}$ & $\begin{array}{l}33.64 \\
32.52 \\
33.55\end{array}$ & $\begin{array}{l}15.69 \\
14.57 \\
15.60\end{array}$ & $\begin{array}{l}1.8916 \times 10^{-5} \\
4.1114 \times 10^{-5} \\
2.0134 \times 10^{-5}\end{array}$ \\
\hline & 18.04 & $\begin{array}{l}28.30 \\
27.21 \\
27.32\end{array}$ & $\begin{array}{r}10.26 \\
9.17 \\
9.28\end{array}$ & $\begin{array}{l}0.00817 \\
0.00174 \\
0.00161\end{array}$ & $\begin{array}{l}33.01 \\
31.70 \\
31.52\end{array}$ & $\begin{array}{l}14.97 \\
13.66 \\
13.48\end{array}$ & $\begin{array}{l}3.1231 \times 10^{-5} \\
7.7434 \times 10^{-5} \\
8.7724 \times 10^{-5}\end{array}$ & & & \\
\hline \multirow[t]{2}{*}{ HA } & 15.76 & $\begin{array}{l}30.07 \\
30.28 \\
29.71\end{array}$ & $\begin{array}{l}14.31 \\
14.52 \\
13.95\end{array}$ & $\begin{array}{l}4.9119 \times 10^{-5} \\
4.2466 \times 10^{-5} \\
6.3042 \times 10^{-5}\end{array}$ & $\begin{array}{l}31.41 \\
31.28 \\
30.60\end{array}$ & $\begin{array}{l}15.65 \\
15.52 \\
14.84\end{array}$ & $\begin{array}{l}1.9403 \times 10^{-5} \\
2.1233 \times 10^{-5} \\
3.4018 \times 10^{-5}\end{array}$ & $\begin{array}{l}34.27 \\
35.67 \\
35.27\end{array}$ & $\begin{array}{l}18.51 \\
19.91 \\
19.51\end{array}$ & $\begin{array}{l}2.6726 \times 10^{-6} \\
1.0127 \times 10^{-6} \\
1.3363 \times 10^{-6}\end{array}$ \\
\hline & 15.91 & $\begin{array}{l}30.85 \\
29.79\end{array}$ & $\begin{array}{l}14.94 \\
13.88\end{array}$ & $\begin{array}{l}3.1814 \times 10^{-5} \\
6.6329 \times 10^{-5}\end{array}$ & & & & & & \\
\hline \multirow[t]{2}{*}{$\mathrm{HM}$} & 14.74 & $\begin{array}{l}23.59 \\
23.63 \\
23.57\end{array}$ & $\begin{array}{l}8.85 \\
8.89 \\
8.83\end{array}$ & $\begin{array}{l}0.00217 \\
0.00211 \\
0.00220\end{array}$ & $\begin{array}{l}23.00 \\
22.86 \\
23.00\end{array}$ & $\begin{array}{l}8.26 \\
8.12 \\
8.26\end{array}$ & $\begin{array}{l}0.00327 \\
0.00360 \\
0.00327\end{array}$ & $\begin{array}{l}22.11 \\
22.09 \\
22.16\end{array}$ & $\begin{array}{l}7.37 \\
7.35 \\
7.42\end{array}$ & $\begin{array}{l}0.00606 \\
0.00614 \\
0.00585\end{array}$ \\
\hline & 15.37 & $\begin{array}{l}24.01 \\
23.95\end{array}$ & $\begin{array}{l}8.65 \\
8.59\end{array}$ & $\begin{array}{l}0.00250 \\
0.00260\end{array}$ & & & & & & \\
\hline $\mathrm{HL}$ & 13.60 & $\begin{array}{l}21.23 \\
21.16\end{array}$ & $\begin{array}{l}7.64 \\
7.57\end{array}$ & $\begin{array}{l}0.00503 \\
0.00528\end{array}$ & $\begin{array}{l}19.50 \\
19.39\end{array}$ & $\begin{array}{l}5.91 \\
5.80\end{array}$ & $\begin{array}{l}0.01669 \\
0.01801\end{array}$ & $\begin{array}{l}22.80 \\
22.65\end{array}$ & $\begin{array}{l}9.21 \\
9.06\end{array}$ & $\begin{array}{l}0.00169 \\
0.00188\end{array}$ \\
\hline
\end{tabular}

$H N$ Human neurons; $H A$ human astrocytes; $H M$ human microglia; $H L$ human leukocytes 


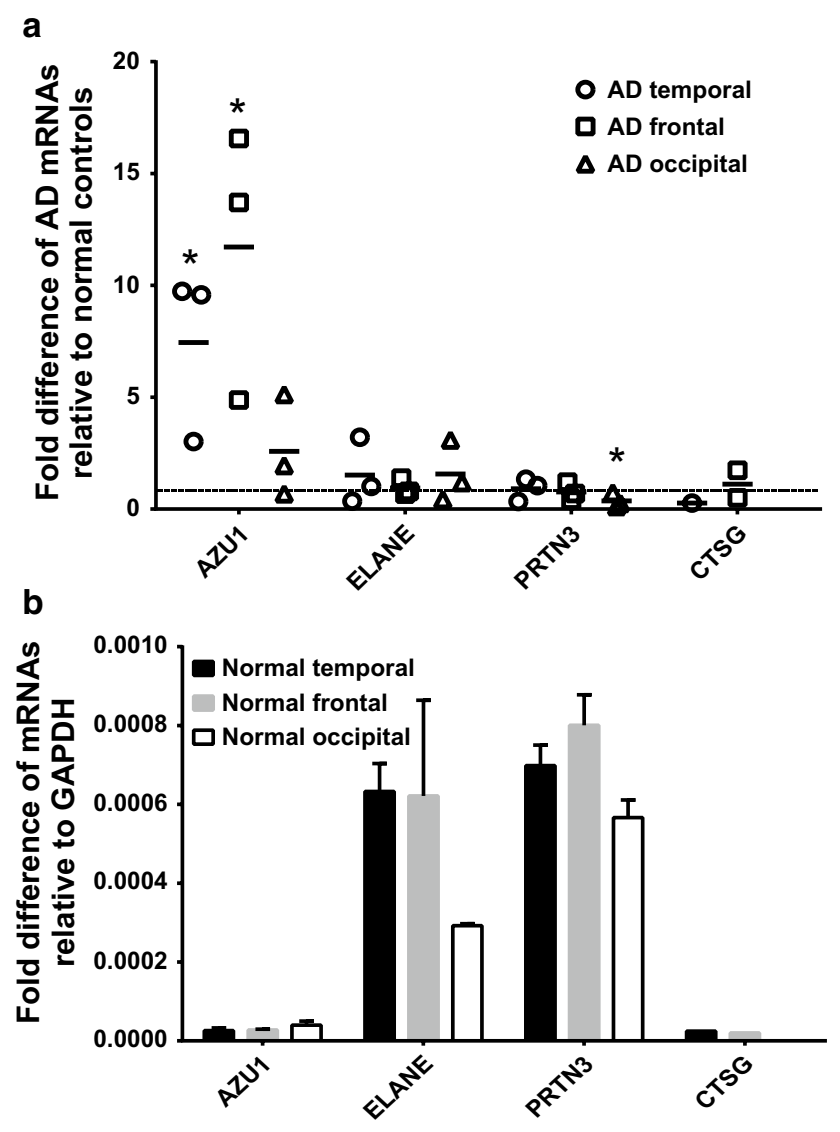

Fig. 7 CAP37 mRNA is upregulated in AD temporal and frontal lobes. AZU1, ELANE, PRTN3, and CTSG mRNA (encode for CAP37, elastase, proteinase-3, and cathepsin G-proteins, respectively) expression was determined by performing qRT-PCR. a Total RNA from tissues from the temporal (circles, $n=3$ ), frontal (squares, $n=3$ ), and occipital lobes (triangles, $n=3$ ) of individual AD patients $(n=6)$ was used. Values are relative to the calculated values of the normal controls for each respective tissue that were each set to 1 (indicated by the dashed line). b Total RNA from the temporal (black bars), frontal (gray bars), or occipital lobes (open bars) of normal adult human controls (five donor pool) expressed as fold differences in mRNAs relative to GAPDH $\left(2^{(-\Delta \mathrm{CT})}\right)$. All values in $\mathbf{a}$ and $\mathbf{b}$ were normalized to $G A P D H$ (internal control). Data are mean \pm SEM of results. ${ }^{*} p<0.05$ (Student's unpaired $t$ test)

from the temporal and frontal lobes of normal controls were loaded as controls for CAP37 migration and expression. Bands of high intensity can be seen for isolated CAP37 (Fig. 9, lane 4) and PMN lysates (Fig. 9, lane 5) between 25 and $30 \mathrm{kDa}$. Low levels of CAP37 were observed in temporal and frontal lobes of normal controls (Fig. 9, lanes 7, 8).

\section{Discussion}

The common phenotype among many neurodegenerative diseases is the death of neurons, which leads to cognitive decline in patients. Therapeutic routes that clinicians and researchers focus on include preventing neuron death, identifying methods to reverse or treat the neuronal damage, or using stem cell therapy to replace the defunct neurons with new healthy neurons. Some researchers focus on a prophylactic approach, which involves identifying early disease biomarkers. Such biomarkers could then be used to determine treatment options before clinical symptoms arise. Further research identifying and characterizing these biomarkers could potentially lead to therapeutics that prevent disease progression.

Unexpectedly, hippocampal staining with IHC herein demonstrated CAP37 expression in brain tissue from two controls that contained mild-to-moderate $\mathrm{AD}$ pathological changes, without showing clinical symptoms of dementia. This surprising finding indicates the potential use of this early increase in CAP37 expression as an early AD biomarker. Changes in protein levels in cerebrospinal fluid (CSF) have recently been demonstrated in forms of dementia, such as AD, and CSF is now considered a key source for identifying biomarkers that predict the onset of dementia (Sun et al. 2003; Kaerst et al. 2013; Kapaki et al. 2013; Scherling et al. 2014). Interestingly, CAP37 has been reported in the CSF at significantly increased levels in patients with bacterial meningitis (Linder et al. 2011). Whether there is an increase or decrease in CAP37 expression in the CSF of AD patients is currently unknown, but it is worth investigating in future studies. We must be able to identify more of these biomarkers that can be detected at early stages of these progressive diseases to determine which are toxic and can be targeted, and which are protective and can potentially be developed into therapeutics.

Within the past 5 years, researchers have postulated that chronic bacterial and viral infections may be responsible for initiating the formation of $\mathrm{A} \beta$ plaques and thus the subsequent pathological events that occur in $\mathrm{AD}$ (Balin et al. 2008; Miklossy 2008; Urosevic and Martins 2008; Bu et al. 2014; Piacentini et al. 2014; Welling et al. 2014). The role of antimicrobial peptides (AMPs) which increase in response to these infections has also been questioned. $\mathrm{A} \beta$ itself has been determined to be an AMP and has also been found to inhibit both the H3N2 and H1N1 influenza A viruses (Soscia et al. 2010; White et al. 2014). As previously mentioned, $\beta$-defensin- 1 is another AMP that is upregulated in AD (Williams et al. 2013). CAP37 can now also be added to this list. Many pathogens that cause chronic infections have been found to compromise the blood-brain barrier which is disrupted in AD (Dickstein et al. 2006; van Sorge and Doran 2012; Erickson and Banks 2013; Marques et al. 2013; White et al. 2014). Notably, CAP37 promotes vascular permeability by inducing rearrangement of the cytoskeleton in endothelial cells and increasing endothelial cell permeability (Gautam et al. 
Fig. 8 CAP37 protein expression is increased in the temporal lobes of an AD patient. Protein lysates $(40 \mu \mathrm{g})$ from an $\mathrm{AD}$ patient and normal control (NC) were electrophoresed with $12.5 \%$ SDS-PAGE gels and transferred to nitrocellulose membranes. Lane order is as follows: Lane 1, NC; lane 2,

$\mathrm{AD}$ sample; lane 3, empty; lane 4 , purified CAP37. Temporal lobe blots were probed with ai monoclonal anti-CAP37 (D5F10) or aii mouse isotype control. CAP37 migrates at $29 \mathrm{kDa}$ in the AD sample on SDS-PAGE gels. CAP37 varies between 28 and $39 \mathrm{kDa}$ depending on its glycosylation state. The mouse isotype control shows no corresponding 29-kDa band. Frontal lobe blots were probed with bi D5F10 or bii mouse isotype control. A 29-kDa band corresponding to the CAP37 molecular weight was observed in both the normal control and the $\mathrm{AD}$ patient with equivalent intensity. A dense band at $\sim 15 \mathrm{kDa}$ was observed in the AD patient lysate, but not in the normal control. Mouse isotype control shows no corresponding 29- or 15-kDa bands
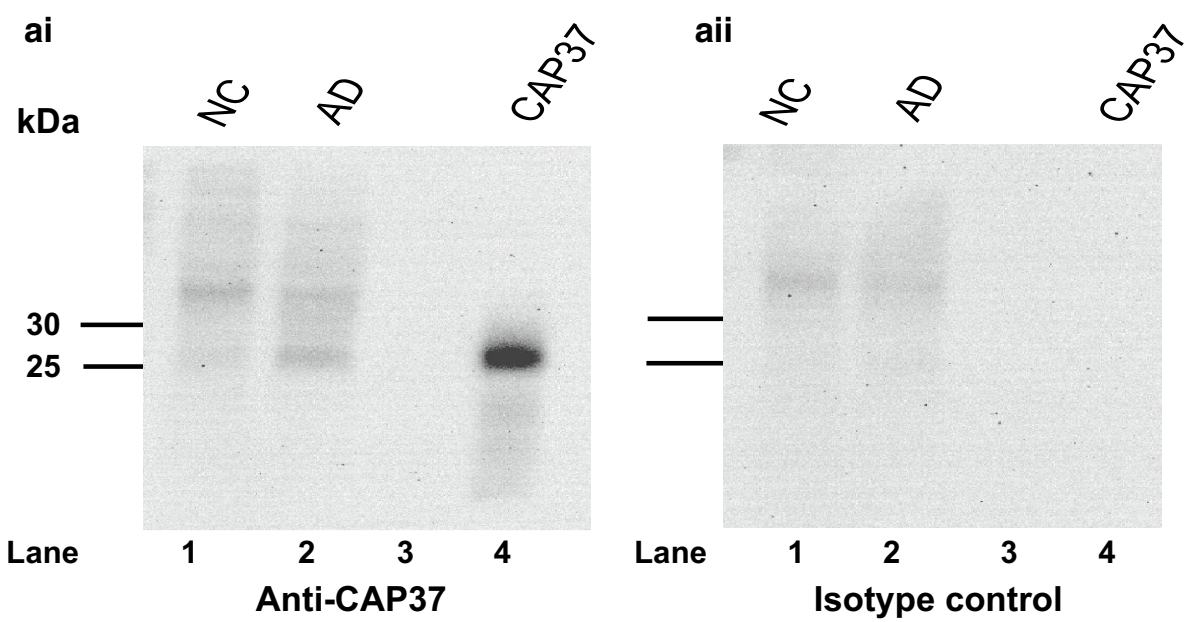

bi

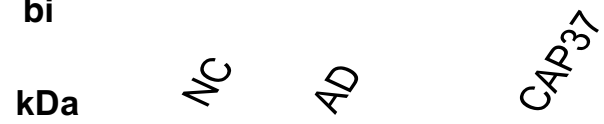

bii

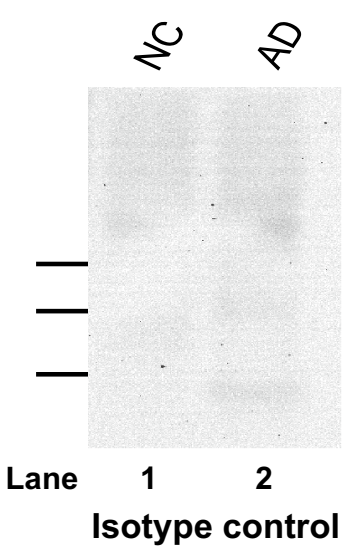

2001; Ley 2001). One study has suggested that CAP37 may be involved in the breakdown of the blood-retinal barrier (Skondra et al. 2008), but direct effects of CAP37 on the blood-brain barrier are currently unknown.

In the present study, we showed that CAP37 is the only neutrophil-derived mRNA of the four analyzed homologs that demonstrates high expression in neurons and increased levels in the AD brain. Although IHC analysis and Western blotting did not reveal CAP37 expression in astrocytes or microglia, we did detect CAP37 transcript in these cells. CAP37, therefore, could potentially be translated and expressed in microglia and astrocytes in other conditions or perhaps pathologies with more acute inflammation. Further studies must be conducted to determine this. The lack of an increase in the neutrophil markers ELANE, PRTN3, and CTSG (Korkmaz et al. 2010 ) in patients with $\mathrm{AD}$ indicates that the increase in $A Z U 1$ (CAP37) expression was not due to an increase in neutrophil influx into the brains of these patients. The low expression of ELANE, PRTN3, and CTSG in neurons and the high expression of these transcripts in brain tissues of normal controls indicate the source of these mRNAs is non-neuronal brain cells such as neutrophils or glial cells.
During $\mathrm{AD}$, the entorhinal cortex is the first region of the brain that is affected, and it acts as a gateway for damage into the hippocampus, where atrophy has been demonstrated in many presymptomatic individuals (Fox et al. 1996; Scahill et al. 2002). As the disease progresses, atrophy begins to occur in the inferior temporal cortex, cingulate cortex, and the precuneus, a region of the superior parietal lobe. In advanced stages of the disease, atrophy of the frontal lobe occurs before eventual spread to the entire neocortex (Scahill et al. 2002; Serrano-Pozo et al. 2011; Khan et al. 2014). Regions of the neocortex that suffer the most severe atrophy include the inferior temporal cortex and the prefrontal cortex, while the occipital cortex is one of the last and least severely impacted (Serrano-Pozo et al. 2011). Herein, we detected CAP37 within pyramidal neuron cell bodies in cortical layers 3 and 5 of the temporal and parietal lobes, which are the specific layers with the most neurofibrillary degeneration in AD (Serrano-Pozo et al. 2011). The levels of CAP37 in neurons of the hippocampus were already elevated in age-matched controls. We did not observe an increase in CAP37 in neurons from this location in patients with AD. Our observation that tissues from 


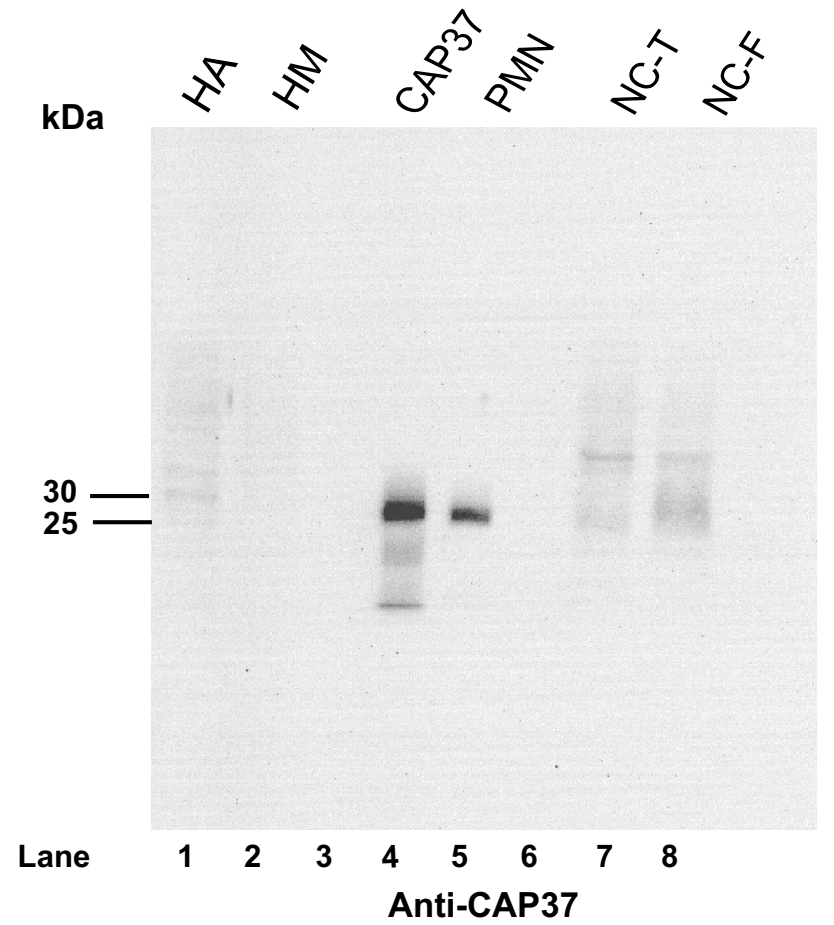

Fig. 9 CAP37 protein is not detected in astrocytes or microglia by Western blotting. Protein lysates in the following order were loaded: lane 1, human astrocytes (HA, $40 \mu \mathrm{g}$ ); lane 2, human microglia (HM, $40 \mu \mathrm{g}$ ); lane 3, empty; lane 4, purified CAP37 (5 ng); lane 5, PMNs $(50 \mathrm{ng})$; lane 6 , empty; lane 7 , normal control brain lysates $(40 \mu \mathrm{g})$ from the temporal lobe (NC-T); lane 8 , normal control brain lysates from the frontal lobe (NC-F) and were electrophoresed with $12.5 \%$ SDS-PAGE gels and transferred to nitrocellulose membranes. Blot was probed with anti-CAP37 (D5F10). No band corresponding to the CAP37 molecular weight was observed in HA or HM lysates

the age-matched controls contained a substantial number of plaques and some neurofibrillary tangles indicates that CAP37 may be an early factor in the disease process. These age-matched control tissues demonstrated pathological changes, but the patients did not show clinical symptoms of dementia. However, based on the progressive nature of $\mathrm{AD}$, there is substantial potential for such clinical symptoms to have developed with increased longevity of the patients. The high increase in CAP37 mRNA and the lack of an increase in CAP37 protein in the frontal lobe suggest that CAP37 may also precede the pattern of atrophy that occurs in $\mathrm{AD}$. We cannot, however, rule out the possibility that the 15-kDa band observed in the frontal lobe of the patient with $\mathrm{AD}$ is a proteolytic degradation product of CAP37 that is only present in the tissues from the patient with $\mathrm{AD}$ and not the control. Many $\mathrm{A} \beta$ degradation products cleaved by enzymes, such as neprilysin and insulin-degrading enzyme, have recently been identified; the role of several altered proteolytic pathways in $\mathrm{AD}$ is under investigation (De Strooper 2010; Saido and Leissring 2012). Whether CAP37 is also degraded or cleaved in particular regions of the brain in AD is currently unknown. The increase in CAP37 in regions severely impacted in AD suggests that $\mathrm{CAP} 37$ may play a role in regulating the toxic events that occur in the specific areas of the brain that suffer the greatest atrophy in $\mathrm{AD}$.

Although we are uncertain whether CAP37 expression induces molecular events that cause $\mathrm{AD}$ progression or is a result of molecular events that arise in $\mathrm{AD}$, our observations indicate that $\mathrm{CAP} 37$ does not directly overlap with $\mathrm{A} \beta$ or tau. The plaques and tangles could spread into CAP37positive regions (or vice versa) with disease progression. Our results using $\mathrm{HCN}-1 \mathrm{~A}$ neurons showed that $\mathrm{A} \beta_{1-40}$ could induce CAP37 expression, while the inactive peptide $\mathrm{A} \beta_{40-1}$ could not. This finding indicates that CAP37 induction is specific to the $A \beta$ structure associated with $A D$ and not to a similar protein sequence found within the inactive peptide. These results also suggest that CAP37 expression may occur after $A \beta$ accumulation. If so, CAP37 would also fall into the microglial activation and inflammatory response stage of the amyloid cascade hypothesis. The amyloid cascade hypothesis posits that $\mathrm{AD}$ pathological events are initiated by $A \beta$, which augments an inflammatory response that leads to oxidative stress, and is followed by tangles and widespread neuron degeneration (Citron 2004, 2010; Harrington 2012; McGeer and McGeer 2013). Most ongoing clinical trials are understandably aimed at targeting $A \beta$ in an attempt to stop cascade initiation. $A \beta$, which may be responsible for many toxic AD events, has a plethora of receptors it can bind and activate (Doens and Fernandez 2014). Blocking $A \beta$, therefore, may block a large number of cellular events that are needed to maintain homeostasis and thus may produce unintended effects. Although anti-inflammatory approaches may not be the central focus for $\mathrm{AD}$ therapeutics, it is plausible that targeting specific molecules responsible for initiating fewer signaling pathways in this component of the cascade may decrease nonspecific events and adverse side effects.

Inflammation in the brain is predominantly driven by resident macrophages known as microglia. These cells function primarily to survey the microenvironment for pathogens, maintain neuronal synaptic integrity, and kill exogenous pathogens. Alterations or disruptions in the homeostasis of the brain are known to activate the microglia, causing them to change from a ramified to ameboid morphology, upregulate specific cell surface receptors, and secrete toxic molecules, including pro-inflammatory cytokines, nitric oxide (NO), and reactive oxygen species (ROS) (Perry et al. 2010). Importantly, CAP37 activates microglial cells by various mechanisms including the ability to change the morphology of microglia from ramified to ameboid, induce the release of pro-inflammatory cytokines, increase the expression of class II major histocompatibility antigens and chemokines, and induce phagocytic and 
chemotactic activities (Pereira et al. 2003). The receptor for CAP37 on microglial cells is currently unknown. However, previous studies from our laboratory suggest that signaling may occur through a G-protein-coupled receptor since CAP37 induced chemotaxis of human corneal epithelial cells is inhibited with pertussis toxin, a known disruptor of GPCR activation (Griffith et al. 2013).

\section{Conclusions}

Based on the results of the present study, we infer that CAP37, an established inflammatory mediator previously shown to activate microglial cells, may mediate the chronic neuroinflammation associated with $\mathrm{AD}$ from within the brain parenchyma. Whether CAP37 could be a potential target or therapeutic is uncertain. However, our data suggest that CAP37 is involved in the AD process, and it should be a strong candidate for further investigation.

Acknowledgments We would like to thank Dr. Eileen Bigio of the Department of Pathology, Northwestern University Feinberg School of Medicine, Alzheimer's Disease Center, Neuropathology Core, for kindly providing us with the brain tissue specimens from patients and age-matched controls that were used for IHC. We are grateful for the funding that we received from the National Eye Institute (NEI) -5R01EY015534 and the Oklahoma Center for the Advancement of Science and Technology (OCAST)-HR12-068 to support this study.

Conflict of interests $\mathrm{H}$. Anne Pereira is the inventor on US Patent $8,450,071$, entitled "Biomarker and method for detecting a chronic inflammatory associated disease." All other authors declare they have no competing interests.

Open Access This article is distributed under the terms of the Creative Commons Attribution 4.0 International License (http://creativecommons.org/licenses/by/4.0/), which permits unrestricted use, distribution, and reproduction in any medium, provided you give appropriate credit to the original author(s) and the source, provide a link to the Creative Commons license, and indicate if changes were made.

\section{References}

Balin BJ, Little CS, Hammond CJ, Appelt DM, Whittum-Hudson JA, Gerard HC, Hudson AP (2008) Chlamydophila pneumoniae and the etiology of late-onset Alzheimer's disease. J Alzheimers Dis 13(4):371-380

Bu XL, Yao XQ, Jiao SS, Zeng F, Liu YH, Xiang Y, Liang CR, Wang QH, Wang X, Cao HY, Yi X, Deng B, Liu CH, Xu J, Zhang LL, Gao CY, Xu ZQ, Zhang M, Wang L, Tan XL, Xu X, Zhou HD Wang YJ (2014) A study on the association between infectious burden and Alzheimer's disease. Eur J Neurol. doi:10.1111/ ene. 12477

Citron M (2004) Strategies for disease modification in Alzheimer's disease. Nat Rev Neurosci 5(9):677-685

Citron M (2010) Alzheimer's disease: strategies for disease modification. Nat Rev Drug Discov 9(5):387-398
Davies BJ, Pickard BS, Steel M, Morris RGM, Lathe R (1998) Serine proteases in rodent hippocampus. J Biol Chem 273(36):23004-23011

De Strooper B (2010) Proteases and proteolysis in Alzheimer disease: a multifactorial view on the disease process. Physiol Rev 90(2):465-494

Dickstein DL, Biron KE, Ujiie M, Pfeifer CG, Jeffries AR, Jefferies WA (2006) Abeta peptide immunization restores blood-brain barrier integrity in Alzheimer disease. FASEB J 20(3):426-433

Doens D, Fernandez PL (2014) Microglia receptors and their implications in the response to amyloid beta for Alzheimer's disease pathogenesis. J Neuroinflammation 11:48

Eikelenboom P, Hoozemans JJ, Veerhuis R, van Exel E, Rozemuller AJ, van Gool WA (2012) Whether, when and how chronic inflammation increases the risk of developing late-onset Alzheimer's disease. Alzheimers Res Ther 4(3): 15

Erickson MA, Banks WA (2013) Blood-brain barrier dysfunction as a cause and consequence of Alzheimer's disease. J Cereb Blood Flow Metab 33(10):1500-1513

Fox NC, Warrington EK, Freeborough PA, Hartikainen P, Kennedy AM, Stevens JM, Rossor MN (1996) Presymptomatic hippocampal atrophy in Alzheimer's disease. A longitudinal MRI study. Brain 119(Pt 6):2001-2007

Gautam N, Olofsson AM, Herwald H, Iversen LF, Lundgren-Akerlund E, Hedqvist P, Arfors KE, Flodgaard H, Lindbom L (2001) Heparin-binding protein (HBP/CAP37): a missing link in neutrophil-evoked alteration of vascular permeability. Nat Med 7(10):1123-1127

Gonzalez ML, Ruan X, Kumar P, Grammas P, Pereira HA (2004) Functional modulation of smooth muscle cells by the inflammatory mediator CAP37. Microvasc Res 67(2):168-181

Grammas P (2011) Neurovascular dysfunction, inflammation and endothelial activation: implications for the pathogenesis of Alzheimer's disease. J Neuroinflammation 8:26

Griffith GL, Russell RA, Kasus-Jacobi A, Thavathiru E, Gonzalez ML, Logan S, Pereira HA (2013) CAP37 activation of PKC promotes human corneal epithelial cell chemotaxis. Invest Ophthalmol Vis Sci 54(10):6712-6723

Griffith GL, Kasus-Jacobi A, Lerner MR, Pereira HA (2014) Corneal wound healing, a newly identified function of CAP37, is mediated by protein kinase $\mathrm{C}$ delta (PKCdelta). Invest Ophthalmol Vis Sci 55(8):4886-4895

Harrington CR (2012) The molecular pathology of Alzheimer's disease. Neuroimaging Clin N Am 22(1):11-22

Heneka MT, O’Banion MK, Terwel D, Kummer MP (2010) Neuroinflammatory processes in Alzheimer's disease. J Neural Transm 117(8):919-947

Hensley K (2010) Neuroinflammation in Alzheimer's disease: mechanisms, pathologic consequences, and potential for therapeutic manipulation. J Alzheimers Dis 21(1):1-14

Kaerst L, Kuhlmann A, Wedekind D, Stoeck K, Lange P, Zerr I (2013) Cerebrospinal fluid biomarkers in Alzheimer's disease, vascular dementia and ischemic stroke patients: a critical analysis. J Neurol 260(11):2722-2727

Kapaki E, Paraskevas GP, Emmanouilidou E, Vekrellis K (2013) The diagnostic value of CSF alpha- synuclein in the differential diagnosis of dementia with Lewy bodies versus normal subjects and patients with Alzheimer's disease. PLoS One 8(11):e81654

Khan UA, Liu L, Provenzano FA, Berman DE, Profaci CP, Sloan R, Mayeux R, Duff KE, Small SA (2014) Molecular drivers and cortical spread of lateral entorhinal cortex dysfunction in preclinical Alzheimer's disease. Nat Neurosci 17(2):304-311

Korkmaz B, Horwitz MS, Jenne DE, Gauthier F (2010) Neutrophil elastase, proteinase 3 and cathepsin $\mathrm{G}$ as therapeutic targets in human diseases. Pharmacol Rev 62(4):726-759 
Lee TD, Gonzalez ML, Kumar P, Chary-Reddy S, Grammas P, Pereira HA (2002) CAP37, a novel inflammatory mediator: its expression in endothelial cells and localization to atherosclerotic lesions. Am J Pathol 160(3):841-848

Ley K (2001) Plugging the leaks. Nat Med 7(10):1105-1106

Linder A, Christensson B, Herwald H, Bjorck L, Akesson P (2009) Heparin-binding protein: an early marker of circulatory failure in sepsis. Clin Infect Dis 49(7):1044-1050

Linder A, Akesson P, Brink M, Studahl M, Bjorck L, Christensson B (2011) Heparin-binding protein: a diagnostic marker of acute bacterial meningitis. Crit Care Med 39(4):812-817

Marques F, Sousa JC, Sousa N, Palha JA (2013) Blood-brain-barriers in aging and in Alzheimer's disease. Mol Neurodegener 8:38

McGeer PL, McGeer EG (2013) The amyloid cascade-inflammatory hypothesis of Alzheimer disease: implications for therapy. Acta Neuropathol 126(4):479-497

Miklossy J (2008) Chronic inflammation and amyloidogenesis in Alzheimer's disease-role of Spirochetes. J Alzheimers Dis 13(4):381-391

Nakajima K, Shimojo M, Hamanoue M, Ishiura S, Sugita H, Kohsaka S (1992) Identification of elastase as a secretory protease from cultured rat microglia. J Neurochem 58(4):1401-1408

Pereira HA (1995) CAP37, a neutrophil-derived multifunctional inflammatory mediator. J Leukoc Biol 57(6):805-812

Pereira HA (2006) Novel therapies based on cationic antimicrobial peptides. Curr Pharm Biotechnol 7(4):229-234

Pereira HA, Shafer WM, Pohl J, Martin LE, Spitznagel JK (1990a) CAP37, a human neutrophil-derived chemotactic factor with monocyte specific activity. J Clin Invest 85(5):1468-1476

Pereira HA, Spitznagel JK, Pohl J, Wilson DE, Morgan J, Palings I, Larrick JW (1990b) CAP 37, a 37 kD human neutrophil granule cationic protein shares homology with inflammatory proteinases. Life Sci 46(3):189-196

Pereira HA, Erdem I, Pohl J, Spitznagel JK (1993) Synthetic bactericidal peptide based on CAP37: a 37-kDa human neutrophil granule-associated cationic antimicrobial protein chemotactic for monocytes. Proc Natl Acad Sci USA 90(10):4733-4737

Pereira HA, Kumar P, Grammas P (1996a) Expression of CAP37, a novel inflammatory mediator, in Alzheimer's disease. Neurobiol Aging 17(5):753-759

Pereira HA, Moore P, Grammas P (1996b) CAP37, a neutrophil granule-derived protein stimulates protein kinase $\mathrm{C}$ activity in endothelial cells. J Leukoc Biol 60(3):415-422

Pereira HA, Ruan X, Kumar P (2003) Activation of microglia: a neuroinflammatory role for CAP37. Glia 41(1):64-72

Pereira HA, Ruan X, Gonzalez ML, Tsyshevskaya-Hoover I, Chodosh J (2004) Modulation of corneal epithelial cell functions by the neutrophil-derived inflammatory mediator CAP37. Invest Ophthalmol Vis Sci 45(12):4284-4292

Perry VH, Nicoll JA, Holmes C (2010) Microglia in neurodegenerative disease. Nat Rev Neurol 6(4):193-201

Piacentini R, De Chiara G, Li Puma DD, Ripoli C, Marcocci ME, Garaci E, Palamara AT, Grassi C (2014) HSV-1 and Alzheimer's disease: more than a hypothesis. Front Pharmacol 5:97
Ruan X, Chodosh J, Callegan MC, Booth MC, Lee TD, Kumar P, Gilmore MS, Pereira HA (2002) Corneal expression of the inflammatory mediator CAP37. Invest Ophthalmol Vis Sci 43(5):1414-1421

Saido T, Leissring MA (2012) Proteolytic degradation of amyloid beta-protein. Cold Spring Harb Perspect Med 2(6):a006379

Scahill RI, Schott JM, Stevens JM, Rossor MN, Fox NC (2002) Mapping the evolution of regional atrophy in Alzheimer's disease: unbiased analysis of fluid-registered serial MRI. Proc Natl Acad Sci USA 99(7):4703-4707

Scherling CS, Hall T, Berisha F, Klepac K, Karydas A, Coppola G, Kramer JH, Rabinovici G, Ahlijanian M, Miller BL, Seeley W, Grinberg LT, Rosen H, Meredith J Jr, Boxer AL (2014) Cerebrospinal fluid neurofilament concentration reflects disease severity in frontotemporal degeneration. Ann Neurol 75(1):116-126

Serrano-Pozo A, Frosch MP, Masliah E, Hyman BT (2011) Neuropathological alterations in Alzheimer disease. Cold Spring Harb Perspect Med 1(1):a006189

Skondra D, Noda K, Almulki L, Tayyari F, Frimmel S, Nakazawa T, Kim IK, Zandi S, Thomas KL, Miller JW, Gragoudas ES, Hafezi-Moghadam A (2008) Characterization of azurocidin as a permeability factor in the retina: involvement in VEGF-induced and early diabetic blood-retinal barrier breakdown. Invest Ophthalmol Vis Sci 49(2):726-731

Soscia SJ, Kirby JE, Washicosky KJ, Tucker SM, Ingelsson M, Hyman B, Burton MA, Goldstein LE, Duong S, Tanzi RE, Moir RD (2010) The Alzheimer's disease-associated amyloid betaprotein is an antimicrobial peptide. PLoS One 5(3):e9505

Sun YX, Minthon L, Wallmark A, Warkentin S, Blennow K, Janciauskiene S (2003) Inflammatory markers in matched plasma and cerebrospinal fluid from patients with Alzheimer's disease. Dement Geriatr Cogn Disord 16(3):136-144

Urosevic N, Martins RN (2008) Infection and Alzheimer's disease: the APOE epsilon 4 connection and lipid metabolism. J Alzheimers Dis 13(4):421-435

van Sorge NM, Doran KS (2012) Defense at the border: the blood-brain barrier versus bacterial foreigners. Future Microbiol 7(3):383-394

Welling MM, Nabuurs RJ, van der Weerd L (2015) Potential role of antimicrobial peptides in the early onset of Alzheimer's disease. Alzheimers Dement 11(1):51-57

White MR, Kandel R, Tripathi S, Condon D, Qi L, Taubenberger J, Hartshorn KL (2014) Alzheimer's associated beta-amyloid protein inhibits influenza A virus and modulates viral interactions with phagocytes. PLoS One 9(7):e101364

Williams WM, Torres S, Siedlak SL, Castellani RJ, Perry G, Smith MA, Zhu X (2013) Antimicrobial peptide beta-defensin-1 expression is upregulated in Alzheimer's brain. J Neuroinflammation 10:127

Wilson CJ, Finch CE, Cohen HJ (2002) Cytokines and cognition-the case for a head-to-toe inflammatory paradigm. J Am Geriatr Soc 50(12):2041-2056 